\title{
SECTION 1981 AFTER RUNYON V. MCCRARY: THE FREE EXERCISE RIGHT OF PRIVATE SECTARIAN SCHOOLS TO DENY ADMISSION TO BLACKS ON ACCOUNT OF RACE
}

The Supreme Court decision in Brown v. Board of Education ${ }^{1}$ prohibiting racial segregation in public schools marked the beginning of a long series of judicial decisions and actions by federal, state and local governments aimed at the elimination of racial discrimination throughout the nation's educational system. ${ }^{2}$ Until recently, the courts had restricted their decisions prohibiting racial discrimination in schools to cases involving some kind of state action; racial discrimination was forbidden if practiced either within a public school system ${ }^{3}$ or by private schools receiving direct or indirect state aid. ${ }^{4}$ In 1976, however, the Supreme Court in Runyon v. McCrary ${ }^{5}$ extended the prohibition against racial discrimination to purely private schools receiving no state aid whatsoever. The Runyon Court held that 42 U.S.C. $\S 1981^{6}$ prohibits private, commercially operated, non-

1. 347 U.S. 483 (1954).

2. See note 137 infra and text accompanying notes 137-38 infra.

3. See, e.g., Swann v. Charlotte-Mecklenburg Bd. of Educ., 402 U.S. 1 (1971); Green v. County School Bd., 391 U.S. 430 (1968); Goss v. Board of Educ., 373 U.S. 683 (1963); Cooper v. Aaron, 358 U.S. 1 (1958); Brown v. Board of Educ., 347 U.S. 483 (1954).

4. See text accompanying notes $162-76$ infra. See, e.g., Gilmore v. City of Montgomery, 417 U.S. 556 (1974) (city enjoined from permitting exclusive access to its recreational facilities by segregated private schools); Norwood v. Harrison, 413 U.S. 455 (1973) (state prohibited from lending textbooks to students in private schools which had racially discriminatory policies); Griffin v. County School Bd., 377 U.S. 218 (1964) (school board enjoined from using public funds to help support segregated private schools); United States v. Mississippi, 499 F.2d 425 (5th Cir. 1974) (state enjoined from subleasing public school facility to private segregated school even if private school promises not to discriminate in its admission policies); Wright $v$. City of Brighton, 441 F.2d 447 (5th Cir.), cert. denied, 404 U.S. 915 (1971) (city enjoined from selling abandoned public school building to segregated private school).

Exemption from federal income tax is considered a form of state aid; consequently, both the Internal Revenue Service and the courts have held that private schools having racially discriminatory policies do not qualify as charitable organizations exempt from federal income tax. Green v. Connally, 330 F. Supp. 1150 (D.D.C. 1971), aff'd mem. sub nom. Coit v. Green, 404 U.S. 997 (1971); Rev. Rul. 75-231, 1975-1 C.B. 158; Rev. Rul; 71-447, 1971-2 C.B. 230; cf. Pitts v. Dep't of Revenue, 333 F. Supp. 662 (E.D. Wis. 1971) (grant of tax exemption to organizations which discriminate on basis of race violates fourteenth amendment). See text accompanying notes $165-69$ infra.

5. 427 U.S. 160 (1976).

6. 42 U.S.C. $\$ 1981$ (1970) provides:

All persons within the jurisdiction of the United States shall have the same right in every State and Territory to make and enforce contracts, to sue, be parties, give evidence, and to the full and equal benefit of all laws and proceedings for the security of persons and property as is enjoyed by white citizens, and shall be subject to like 
sectarian schools from denying admission to students solely on account of race. ${ }^{7}$ Because the Court expressly noted that the private schools in Runyon did not attempt to justify their discriminatory policies on the basis of a religious belief, ${ }^{8}$ the Runyon decision effectively outlawed the practice of racial discrimination in every type of educational institution except private sectarian schools that practice racial exclusion on religious grounds. ${ }^{9}$

The issue of whether a private sectarian school can, pursuant to the free exercise of its religion under the first amendment, discriminate against

punishment, pains, penalties, taxes, licenses, and exactions of every kind, and to no other.

Section 1981 is derived from section 1 of the Civil Rights Act of 1866. The legislative history of section 1981, with respect to its relationship to the thirteenth and fourteenth amendments and its ability to reach private action, was reviewed by the Runyon Court. 427 U.S. at 168 n.8, 168-72, 173-74. See generally Johnson v. Railway Express Agency, 421 U.S. 454, 459-60 (1975); Tillman v. Wheaton-Haven Recreation Ass'n, 410 U.S. 431, $439-40$ (1973); Note, The Desegregation of Private Schools: Is Section 1981 the Answer?, 48 N.Y.U.L. REv. 1147 (1973); see also Jones v. Alfred H. Mayer Co., 392 U.S. 409, 422-36 (1968) (examining the nearly identical legislative history of 42 U.S.C. $\$ 1982$ which, like section 1981 , was also derived from section 1 of the Civil Rights Act of 1866).

7. Runyon was the consolidation of two cases, Runyon v. McCrary and Fairfax-Brewster School, Inc. v. Gonzales, both involving similar fact situations. The plaintiffs were black children who had inquired about or applied for admission to private nonsectarian schools. The district court found that the schools had rejected the children's applications on account of their race. In affirming the decision of the Fourth Circuit Court of Appeals in favor of the plaintiffs, McCrary v. Runyon, 515 F.2d 1082 (4th Cir. 1975), the Supreme Court held that 42 U.S.C. $\S$ 1981, which prohibits racial discrimination in the making and enforcement of private contracts, applies to the admission of students to private schools and that the racial exclusion practiced by the schools in Runyon "amounts to a classic violation of $\$ 1981$." 427 U.S. at 172. The Court also held that section 1981 as applied did not violate constitutionally protected rights of free association and privacy, or a parent's right to direct the education of his children. Although the Court acknowledged the existence of such rights, it stated that the application of section 1981 was not a deprivation or infringement of any constitutional or parental rights claimed by the schools on behalf of themselves or their patrons. Id. at 175-79. See text accompanying notes 175-76 infra.

8. The Court stated that Runyon did not "present the application of $\S 1981$ to private sectarian schools that practice racial exclusion on religious grounds, " 427 U.S. at 167 (emphasis omitted), and that "[n]othing in this record suggests that either the Fairfax-Brewster School or Bobbe's Private School excludes applicants on religious grounds, and the Free Exercise Clause of the First Amendment is thus in no way here involved." Id. at 167 n.6. The Court was most likely prompted to take note of the absence of any free exercise of religion issue in Runyon by an amicus curiae brief filed by Dade Christian Schools, Inc. requesting "that if this Court should determine that private schools are subject to $\S 1981$, a caveat be incorporated into the decision of this Court leaving open the possibility that a legitimate claim under the Free Exercise Clause would defeat a $\$ 1981$ claim." Brief of Dade Christian Schools, Inc., as Amicus Curiae at 27, Runyon v. McCrary, 427 U.S. 160 (1976).

9. By emphasizing the "commercial" nature of the private schools in Runyon, the Court also left open the possibility of allowing the practice of racial discrimination by "noncommercially operated" private schools. For a discussion of the commercial/noncommercial distinction and its significance with respect to the application of section 1981 to private schools, see text accompanying notes $148-52,182-83$ infra. 
blacks in its admission policies was squarely raised by the parties in Brown v. Dade Christian Schools, Inc. ${ }^{10}$ (hereinafter cited as Brown). The plaintiffs were two black minor children and their parents. Mrs. Brown had gone to the premises of Dade Christian Schools, Inc. (Dade Christian) for the purpose of enrolling her daughters in the day school program. Before she had completed the application forms, she was handed a printed card which stated that "the policy of the school is one of non-integration and we would request that you respect this policy." 11 The Browns brought an action under section 1981 against Dade Christian and four past and present officers of the school seeking damages and an injunction to prevent the school from barring the children from enrolling on account of their race. The parties stipulated that race was the sole reason for Dade Christian's denying admission to the Brown children. ${ }^{12}$ The school's affirmative defense was that its members sincerely held a religious belief "forbidding the commingling of the white and black races under circumstances which may tend to promote interracial marriage." 13

After a nonjury trial, the trial judge found that Dade Christian's refusal to admit the Brown children was not based upon a sincerely held religious belief, but rather upon a "policy" or "philosophy" which, although it could be justified "in the Scriptures," was not entitled to protection under the free exercise clause of the first amendment. ${ }^{14}$ The district court thus did not reach the issue of whether a claim under section 1981 outweighs an opposing first amendment claim, ${ }^{15}$ and merely followed the decision of the Fourth Circuit Court of Appeals in McCrary v. Runyon ${ }^{16}$ in enjoining Dade Christian from barring the Brown children from enrolling because of their

10. 556 F.2d 310 (5th Cir. 1977) (en banc), cert. denied, 46 U.S.L.W. 3526 (U.S. Feb 21, 1978). Dade Christian was a sectarian school, located on the property of and receiving subsidies from the New Testament Baptist Church. According to the Brief of Appellant at 3, "[s]ince its founding, the operating policies of Dade Christian have been formulated and prescribed by the New Testament Baptist Church." Dade Christian's students, however, were not limited to those in families of church members and the school advertised in the "Yellow Pages" section of the local telephone directory.

11. 556 F.2d at 311 .

12. No such stipulation was made in Runyon; however, the district court in Runyon found as a matter of fact that the plaintiffs had been denied admission on racial grounds and, apparently, this finding was not contested by the defendants. 427 U.S. at 165.

13. Paragraph 18 of Defendant's Amended Answer, quoted in Brief of Appellant, Brown v. Dade Christian Schools, Inc., 556 F.2d 310 (5th Cir. 1977), cert. denied, 46 U.S.L.W. 3526 (U.S. Feb. 21, 1978), at 10.

14. Brown v. Dade Christian Schools, Inc., No. 73-1313 -Civ -JE, slip op. at 4 (S.D. Fla., May 28, 1975) (Findings of Fact and Conclusions of Law). The free exercise clause states: "Congress shall make no law . . . prohibiting the free exercise [of religion]."

15. Slip op. (Findings of Fact and Conclusions of Law) at 3.

16. 515 F.2d 1082 (4th Cir. 1975), aff'd, 427 U.S. 160 (1976). At the time of the district court's decision-May 28, 1975-the Runyon case had not yet reached the Supreme Court. 
race. ${ }^{17}$ The Fifth Circuit Court of Appeals heard Dade Christian's appeal en banc and a bare majority of seven judges voted to affirm the district court's decision. ${ }^{18^{\circ}}$ There was no majority opinion, however, as only five judges agreed with the district court's findings and analysis. Two concurring judges would have reached the balancing question and would have held that the governmental interest in prohibiting the practice of racial discrimination outweighed any first amendment claim presented by the school. ${ }^{19}$ The six dissenting judges argued that Dade Christian's admission policies did reflect a religious belief but, while agreeing with the concurring judges that a balancing of the opposing interests was necessary, they would have remanded the case to the district court to strike the balance. ${ }^{20}$

This Comment will analyze the legal issues presented by the case of a private sectarian school that denies admission to blacks on the basis of a claimed religious belief. The threshold determination of whether a belief is sincerely held and whether it may be considered a religious belief will be examined, followed by a discussion of the nature of the first amendment's guarantee of the free exercise of religion. After determining that the first amendment does not protect all activities conducted pursuant to religious beliefs from infringement or from the imposition of burdens by governmental regulation, the Comment will review Supreme Court decisions which have balanced the state's and the free exercise claimant's respective interests. Finally, the state's interest embodied in section 1981 and a private school's interest in practicing its religion will be evaluated and balanced against one another. The Comment will conclude that the state's compelling interest in the elimination of racial discrimination in public and private schools at least in some cases outweighs the first amendment free exercise rights of individuals and institutions who hold religious beliefs requiring the practice of racial segregation.

17. Brown v. Dade Christian Schools, Inc., No. 73-1313 -Civ -JE, slip op. at 1-2 (S.D. Fla., June 27, 1975) (Final Judgment and Injunction). The district court also ordered Dade Christian to pay compensatory damages to the plaintiffs. The individual defendants were held not liable for damages. Id. at 1.

18. 556 F.2d 310 (5th Cir. 1977).

19. Although both of the concurring judges would have reached the merits of the constitutional issue, Judge Brown did not determine whether or not Dade Christian's admission policies were actually based upon a religious belief. He merely concluded that the school's first amendment claim, "if any," was outweighed by the governmental interest in desegregation. Id. at 314 (Brown, J., concurring). Judge Goldberg did find that the school's segregationist policy was religious in nature. Id. at 314-20 (Goldberg, J., specially concurring).

20. Id. at 326 (Roney, J., dissenting). One of the dissenters, Judge Coleman, went further by stating that "no court should have the power to compel any church to admit any student to any school operated for religious reasons." Id.

For a more detailed analysis of the district court and Fifth Circuit decisions see 91 HARV. L. REV. 879 (1978). 


\section{The Threshold Determination: When Is a Belief "Religious"?}

As the Brown plurality's disposition of the case made clear, before a court can attempt to balance a private sectarian school's free exercise rights against the government's interest in the elimination of racial discrimination in private schools, it is first necessary to determine whether the school's admission policy of racial exclusion is actually based upon a religious belief. ${ }^{21}$ Several courts have attempted to define the term "religion," 22 but

21. Attempts to identify the determination of whether a belief is religious as a question of law or as a question of fact have been the source of much confusion within the courts. As a result of the Supreme Court's failure to provide a definitive statement with respect to this issue, the courts have been split or, more typically, have simply not bothered to label their inquiry into the nature of the belief as being either a legal or a factual determination. Courts frequently avoid the issue by stating that whether or not a belief is religious is a question to be decided "by the courts." See, e.g., Stevens v. Berger, 428 F. Supp. 896, 899 (E.D.N.Y. 1977); United States v. Kuch, 288 F. Supp. 439, 443 (D.D.C. 1968); Borchert v. City of Ranger, 42 F. Supp. 577,580 (N.D. Tex. 1941); cf. United States v. Seeger, 380 U.S. 163, 184-85 (1965) (whether draft registrant's beliefs are religious to be decided by local draft boards and courts), quoted in United States v. Welsh, 398 U.S. 333, 339 (1970) (plurality opinion). Although the Brown plurality twice stated that whether an activity constitutes the exercise of religion is a question of fact, $556 \mathrm{~F} .2 \mathrm{~d}$ at 313,314 , the Supreme Court has generally taken upon itself the task of determining whether an activity may be considered the exercise of religion. See, e.g., Wisconsin v. Yoder, 406 U.S. 205 (1972) (refusal by Amish parents to send children to school past eighth grade); West Virginia Bd. of Educ. v. Barnette, 319 U.S. 624 (1943) (refusal to salute American flag); Murdock v. Pennsylvania, 319 U.S. 105 (1943) (door-to-door distribution of literature and solicitation of sale of books); Davis v. Beason, 133 U.S. 333 (1890) (practice of polygamy); cf. Welsh v. United States, 398 U.S. 333 (1970); United States v. Seeger, 380 U.S. 163 (1965) (Selective Service registrants claiming status as religious conscientious objectors). In no case has the Court deferred to the judgment of the trial judge or jury; rather, the Court in each case has made an independent assessment of the facts and reached its own conclusions as to whether the beliefs and actions in question were entitled to first amendment protection. This approach by the Court is consistent with its frequent references to the "preferred position" of freedom of religion as a first amendment right and to the consequent need for an appellate court's de novo review of the facts. See, e.g., Marsh v. Alabama, 326 U.S. 501, 509 (1946); Thomas v. Collins, 323 U.S. 516, 530 (1945); Murdock v. Pennsylvania, 319 U.S. 105, 115 (1943). "Because a claim of constitutionally protected right is involved, it 'remains our duty in a case such as this to make an independent examination of the whole record.' Edwards v. South Carolina, 372 U.S. 229, 235 [1963]." Cox v. Louisiana, 379 U.S. 536, 545 n.8 (1965) (first amendment rights) (citing Blackburn v. Alabama, 361 U.S. 199, 205 n.5 (1960), and Pennekamp v. Florida, 328 U.S. 331,335 (1946)).

In this respect, the determination of the religious nature of a belief may be considered a question of "constitutional fact" and is closely analogous to the determination in a defamation action of whether the plaintiff is a public or a private figure. The distinction between public and private figure plaintiffs determines the standard by which the defendant's liability is ascertained and thereby constitutes a potential infringement of the defendant's "preferred" first amendment rights of freedom of press and speech. The Court stated in Rosenblatt v. Baer, 383 U.S. 75,88 \& $\mathrm{n} .15$ (1966), that the determination of whether a defamation plaintiff is a public official "is for the trial judge in the first instance to determine" and is a "constitutional decision" subject to review by appellate courts. Since a decision of constitutional magnitude is involved, appellate courts have the duty to "review the evidence to make certain that those [constitutional] principles have been constitutionally applied." New York Times Co. v. Sullivan, 376 U.S. 254, 285 (1964), quoted in Greenbelt Cooperative Pub. Ass'n v. Bresler, 398 U.S. 
it is hardly surprising, considering the extremely sensitive nature of the

6, 11 (1970). A similar approach is employed in determining whether the allegedly defamatory statement was made with knowing or reckless disregard of its falsity. The reasons offered by the Rosenblatt Court for having the trial judge make these initial findings are equally applicable to the determination of whether a belief is religious: "Such a course will both lessen the possibility that a jury will use the cloak of a general verdict to punish unpopular ideas or speakers, and assure an appellate court the record and findings required for review of constitutional decisions." 383 U.S. at 88 n.15. See generally P. BREST, ProCESSES OF CONSTITUTIONAL DECISIONMAKING 894-953 (1975) (chapter on constitutional facts).

On the basis of the Supreme Court's treatment of freedom of religion cases, it appears that the determination of whether the beliefs underlying a private sectarian school's admission policy are religious is best viewed as "a mixed question of law and fact, involving as it does the application of a legal standard to a particular set of facts." TSC Industries, Inc. v. Northway, Inc., 426 U.S. 438,450 (1976) (referring to the determination of whether a fact is "material" with respect to proxy solicitations). Courts are responsible for establishing, as a matter of law, standards for distinguishing religious and nonreligious beliefs, but these standards must be applied to the facts involved in particular cases in order to decide whether the claimed belief of a private school is entitled to first amendment protection. This is also the conclusion reached by Judge Goldberg in his concurring opinion in Brown. 556 F.2d at 316. It should be noted that identifying the determination of whether a belief is religious as a mixed question of law and fact, rather than a question of fact, is not simply a theoretical legal distinction; it is a matter of great practical significance at both the trial and appellate levels. At trial, it is essential for the judge to know if a particular question must be determined by the jury or by the judge himself, or a combination of the two. At the appellate level, the standard of appellate review of the trial court's findings is contingent upon the nature of the issues decided. If a factual issue is involved, the appellate court will apply a much more lenient standard of review and will not reverse the trial court's findings "unless clearly erroneous." FED. R. Civ. P. 52(a). Since the Brown plurality termed the district court's finding that Dade Christian's policy of racial exclusion was not the exercise of religion a factual determination, the plurality was willing to affirm the finding so long as it was supported by "substantial" evidence. 556 F.2d at 312 . Judge Goldberg, on the other hand, argued that the court of appeals had a responsibility to exercise its "own independent judgment" and to assess the facts to determine whether Dade Christian's belief was religious. Id. at 316-17. Goldberg also asserted that there was no reason to defer to the judgment of the trial court because of its opportunity, in theory, to judge the credibility of the witnesses since the case had been tried solely on the basis of depositions and exhibits and no witnesses had testified. Id. at 317.

22. See, e.g., United States v. Macintosh, 283 U.S. 605, 633 (1931) (Hughes, C.J., dissenting), overruled on other grounds, Girouard v. United States, 328 U.S. 61 (1946) ("The essence of religion is belief in a relation to God involving duties superior to those arising from any human relation"), quoted in United States v. Seeger, 380 U.S. 163, 175 (1965) (this language was incorporated nearly verbatim in the Universal Military Training and Service Act, $\$ 6(j), 62$ Stat. 612 (1948) (current version at 50 U.S.C. app. $\$ 456(j)$ (Supp. V 1975)), quoted at note 50 infra); Davis v. Beason, 133 U.S. 333, 342 (1890) ("The term 'religion' has reference to one's views of his relations to his Creator, and to the obligations they impose of reverence for his being and character, and of obedience to his will"); United States v. Kauten, 133 F.2d 703, 708 (2d Cir. 1943); cf. Welsh v. United States, 398 U.S. 333, 339 (1970) (plurality opinion) (individual who "deeply and sincerely holds beliefs that are purely ethical or moral in source and content but that nevertheless impose upon him a duty of conscience to refrain from participating in any war at any time . . . is . . . entitled to a 'religious' conscientious objector exemption" under Universal Military Training and Service Act); United States v. Seeger, 380 U.S. 163, 176 (1965) (phrase "religious training and belief" means "all sincere religious beliefs which are based upon a power or being, or upon a faith, to which all else is subordinate or upon which all else is ultimately dependent").

The theism present in the earlier definitions of religion contained in Davis and Macintosh 
subject, ${ }^{23}$ that most courts have avoided the difficult, if not impossible, task of formulating a precise functional definition. ${ }^{24}$ However, notwithstanding the inability of courts to adequately express the meaning of "religion," "there is little doubt that as it was used in the First Amendment it was

has been replaced by the broader concepts expressed in Kauten, Seeger and Welsh. See text accompanying notes 54-56 infra. This shift in judicial attitude was made evident in Torcaso v. Watkins, 367 U.S. 488 (1961), in which the Court referred to "religions based on a belief in the existence of God as against those religions founded on different beliefs." Id. at 495. See generally M. Konvitz, ReLigious LiberTy AND CONSCIENCE 27-72 (1968); L. TRIBE, AMERICAN CONSTITUTIONAL LAW \& 14-6 (1978); Boyan, Defining Religion in Operational and Institutional Terms, 116 U. PA. L. REV. 479 (1968); Galanter, Religious Freedoms in the United States: A Turning Point?, 1966 WIS. L. REv. 217, 255-68; Silving, The Unknown and the Unknowable in Law, 35 CAL. L. Rev. 352, 365-74 (1947); Comment, Defining Religion: Of God, the Constitution and the D.A.R., 32 U. CHI. L. REv. 533 (1965); Note, Toward a Constitutional Definition of Religion, 91 HARV. L. REV. 1056 (1978).

23. The determination of whether a belief is religious may present "a most delicate question." Wisconsin v. Yoder, 406 U.S. 205, 215 (1972); accord, Stevens v. Berger, 428 F. Supp. 896, 900 (E.D.N.Y. 1977) ("Delicacy in probing and sensitivity to permissible diversity is required, lest established creeds and dogmas be given an advantage over new and changing modes of religious belief").

24. "It is unnecessary to attempt a definition of religion; the content of the term is found in the history of the human race and is incapable of compression into a few words." United States v. Kauten, 133 F.2d 703, 708 (2d Cir. 1943), quoted in West Virginia State Bd. of Educ. v. Barnette, 319 U.S. 624, 658 (1943) (Frankfurter, J., dissenting) (but see attempted definition of religion by Kauten court, 133 F.2d at 708); see Theriault v. Carlson, 495 F.2d 390, 395 (5th Cir.), cert. denied, 419 U.S. 1003 (1974) ("it is difficult for the courts to establish precise standards by which the bona fides of a religion may be judged") (footnote omitted); L. PFEFFER, CHuRCH, STATE AND FREEDOM 609 (rev. ed. 1967) ("The term religion may not be subject to precise definition"); Galanter, supra note 22, at 264 ("the application of any 'objective' criterion of the boundaries of religion is rendered extremely difficult. There now remains no valid test of the content of a claimed religious belief"); Weiss, Privilege, Posture and Protection: "Religion" in the Law, 73 YALE L.J. 593, 604 (1964) ("to define the limits of religious expression may be impossible if philosophically desirable"); Silving, supra note 22, at 366-67.

Some courts and commentators have taken the inability of courts to formulate a workable definition of religion one step further, arguing that to even attempt to define religion would in itself violate the first amendment. Kolbeck v. Kramer, 84 N.J. Super. 569, 202 A.2d 889 (1964), modified on other grounds per curiam, 46 N.J. 46, 214 A.2d 408 (1965); see M. KonVITZ, supra note 22, at 50 ("the very meaning or definition of 'religion,' as the term is used in the First Amendment, should be outside the area of governmental inquiry"); $c f$. West Virginia State Bd. of Educ. v. Barnette, 319 U.S. 624, 658 (1943) (Frankfurter, J., dissenting) (Supreme Court cannot constitutionally determine what claims of conscience should be recognized as constituting "religion" entitled to first amendment protection). See also Catholic Bishop v. NLRB, 559 F.2d 1112 (7th Cir. 1977), cert. granted, 46 U.S.L.W. 3526 (U.S. Feb. 21, 1978) (NLRB jurisdiction over secondary diocesian schools operated by Roman Catholic Church would violate Church's right to free exercise of religion; "reasonable accommodation" by NLRB to religious purposes of school in unfair labor practice case would implicitly "involve the necessity of explanation and analysis, and probably verification and justification, of the doctrinal precept involved, all of which would itself erode the protective wall afforded by the constitutional right"); D. Manwaring, Render Unto Caesar: The FlaG-SaluTE Controversy 51 (1962). This argument is similar to that adopted by some commentators and courts who state that an individual's claim that his belief is religious should be determinative of whether his belief is protected by the first amendment. See note 35 infra and accompanying text. 
intended to have and has been interpreted by the Supreme Court as having a broad and comprehensive meaning." 25

The determination of when a belief is "religious" has been the source of much judicial confusion due to the failure of courts to restrict their inquiry to the limited number of factors which may constitutionally be considered. The only two issues which courts can legitimately address are whether the belief in question is based upon religious, rather than secular, doctrines and whether it is sincerely and honestly held. In making these determinations, courts must be careful not to examine the reasonableness, believability or truth of the allegedly religious belief; judicial inquiry into such matters is forbidden by the free exercise clause. ${ }^{26}$ Yet courts sometimes fail to distinguish such questions from the central issues of the sincerity and religious nature of the belief. This distinction is especially significant with respect to a claimed religious belief prohibiting social interaction between races under circumstances that may lead to racial intermarriage. Because most people would consider such a belief to be unreasonable and unbelievable, the inclination on the part of the courts would be to conclude that the belief is not religious. Nevertheless, if the court finds that the claimants sincerely hold the belief and that it is religious in nature, questions of reasonableness and believability are completely irrelevant.

\section{A. Private Versus Institutional Beliefs.}

A preliminary matter that must be addressed before determining whether the beliefs underlying a private school's admission policy are religious in nature is identifying whose beliefs are at issue-the individual's or the institution's. This is a potentially decisive distinction, as demonstrated in Brown, ${ }^{27}$ because even if all the patrons of a private school and all

25. L. PFEFFER, supra note 24, at 609. Accord, Galanter, supra note 22, at 264 ("the Court has broadened its notion of religion to include all beliefs which are sincere, meaningful, and paramount in the lives of their holders"); Weiss, supra note 24, at 604; see, e.g., Malnak v. Yogi, 440 F. Supp. 1284, 1314 (D.N.J. 1977); cf. Welsh v. United States, 398 U.S. 333 (1970) (statutory interpretation); United States v. Seeger, 380 U.S. 163, 186 (1965) ("We have construed the statutory definition [of religious belief] broadly and it follows that any exception must be interpreted narrowly"); Bridges v. California, 314 U.S. 252, 263 (1941) (freedom of speech and press) (first amendment "must be taken as a command of the broadest scope"). See note 87 infra and text accompanying notes $87-89$ infra.

26. See note 79 infra and accompanying text.

27. The Brown plurality emphasized that since the refusal by Dade Christian to admit black children "was an institutional action taken by an institution whose patrons are, according to the evidence, divided in their beliefs on the religious justification for racial segregation," the religious beliefs being examined were the "corporate beliefs of the institution" and not those of individuals. 556 F.2d at 313-14 (emphasis added). "To do otherwise," said the plurality, "would allow the institution to pick and choose which of its members' potentially conflicting beliefs it wishes to assert at any given time." Id. at 313. As a result of its "institutional approach" to the religious question, the plurality refused to rely upon otherwise relevant cases such as Wisconsin 
the members of its parent church sincerely hold religious beliefs requiring the practice of racial discrimination, the court could find that the school, as an institution, possesses no such belief and thus is not entitled to defend its policy of racial exclusion on first amendment grounds. Moreover, even if the school as an institution is found to possess the requisite belief, it is uncertain whether a religious organization possesses institutional rights of free exercise of religion under the first amendment. ${ }^{28}$ The Supreme Court has held that the first amendment freedoms of speech and assembly, as secured by the due process clause of the fourteenth amendment, are guaranteed only to natural persons, ${ }^{29}$ and the consensus of the authorities is that the same limitation applies to the guaranty of the free exercise of religion. ${ }^{30}$ More recently, however, the Court has implicitly recognized that religious organizations may have constitutionally protected rights which are distinct from those of the persons comprising the organization. ${ }^{31}$

Assuming arguendo that a private school does have free exercise rights peculiar to itself, it is conceivable that there could exist a private sectarian school that excludes blacks on the basis of a purely secular racial segregation policy but whose patrons all hold sincere religious beliefs commanding separation of the races. In an action against such a school by black children who had been denied admission, the court might properly under Runyon apply section 1981's prohibition of racial discrimination because the school

v. Yoder, 406 U.S. 205 (1972), and Gillette v. United States, 401 U.S. 437 (1971), because they involved governmental regulation of individual, rather than institutional, religious beliefs. 556 F.2d at 313. The plurality acknowledged that, had it examined the beliefs of the individual members of the church, it could have found Dade Christian's policy of racial exclusion to be the exercise of religion. Id. at 312 n.4. Judge Goldberg emphatically disagreed with the plurality over this issue, arguing that the court's focus should be upon the individual religious beliefs of Dade Christian's students, their parents and other members of the New Testament Baptist Church. Id. at 315-16. See generally Note, Section 1981 Applicable to Private School Admissions, 25 KAN. L. REv. 247, 253 (1977); Galanter, supra note 22, at 264 (noting distinction between individuals and institutions with respect to determining whether a belief is religious).

28. See Brown, 556 F.2d at 313, 316 n.4; cf. Note, The Wall of Racial Separation: The Role of Private and Parochial Schools in Racial Integration, 43 N.Y.U.L. REV. 514, 531 n.120 (1968) ("It is questionable whether the Church has a constitutional right of freedom of religion which encompasses the operation of a parochial school system which discriminates on religious grounds").

29. Hague v. CIO, 307 U.S. 496, 514, 527 (1939).

30. See, e.g. , Howe, Political Theory and the Nature of Liberty, 67 HARV. L. Rev. 91, 91-92 (1953); Pfeffer, Religion in the Upbringing of Children, 35 BosTON U.L. Rev. 333, 341 (1955); Note, supra note 28 , at 531 n.120.

31. Kedroff v. Saint Nicholas Cathedral, 344 U.S. 94 (1952) (state statute transferring property of Russian Orthodox Church from control of Moscow Archbishop to American Archbishop directly violates Church's ecclesiastical right of choice of its hierarchy); see Howe, supra note 30, at 92-95; Pfeffer, supra note 30, at 341 \& $\mathrm{n} .56$ and authorities cited therein; Note, supra note 28, at 531 n.120; cf. Swan v. First Church of Christ, Scientist, 225 F.2d 745, 750-51 (9th Cir. 1955) (religious organizations are protected by first amendment from state interference with their right to designate what writings shall be accepted by their members). 
as an institution would not be practicing its religion by excluding blacks. However, if the school were enjoined from denying admission to blacks, the free exercise rights of the school's patrons would be infringed without having been asserted in court. In order to avoid this inequitable and perhaps unconstitutional result, the school should be granted standing to assert the constitutional rights of its students, their parents and of the church members as a defense to an action under section 1981. The court would thereby insure that first amendment rights were not inadvertently abridged and would avoid having to decide whether organizations possess free exercise rights independent of their members. ${ }^{32}$ The Runyon Court did not hesitate to allow private schools standing to assert the parents' constitutionally protected rights of free association and privacy. ${ }^{33}$ Although Runyon involved associational as opposed to free exercise rights, there would appear to be no substantive basis for distinguishing between the two for standing purposes.

\section{B. Constitutionally Permissible Factors.}

The courts regularly consider several factors in determining whether a particular belief is "religious." These factors include: the claimant's own statements as to the religious nature of his belief, the time of the acquisition of the belief, the source of the belief, the existence or nonexistence of writings documenting the religious nature of the belief and the relative importance of the belief with respect to the claimant's religion. ${ }^{34}$

32. This was the view adopted by Judge Goldberg in Brown, 556 F.2d at 315 . Even if some of Dade Christian's patrons supported racial segregation upon secular, rather than religious, grounds, their rights would by no means be infringed by granting the school standing to assert the free exercise rights of other patrons.

It is undisputed that patrons of Dade Christian possess the right to the free exercise of their religion and that they have standing to assert violations or infringements of that right. See McGowan v. Maryland, 366 U.S. 420, 429-30 (1961) (standing under free exercise clause requires infringement of individual's religious freedom); School Dist. of Abington Twp. v. Schempp, 374 U.S. 203, 224 n.9; Kauper, Church, State, and Freedom, 52 MicH. L. Rev. 829, 833-34 (1954). See generally Flast v. Cohen, 392 U.S. 83, 99-104 (1968).

33. 427 U.S. at 175 n.13. Cf. Craig v. Boren, 429 U.S. 190, 192-94 (1977) (saloon proprietor has standing to assert constitutional rights of patrons); NAACP v. Alabama, 357 U.S. 449, 45860 (1958) (association has standing to assert the constitutional right to freedom of association on behalf of its members); Barrows v. Jackson, 346 U.S. 249, 255-59 (1953) (white defendant has standing to assert fourteenth amendment equal protection rights of blacks not a party to the action). See generally Note, Standing to Assert Constitutional Jus Tertii, 88 HaRv. L. Rev. 423 (1974).

34. This listing is not meant to imply that all these factors must be or are taken into consideration by the courts before a determination can be made as to the existence of a religious belief; it is, rather, a compilation of various factors that have been used by different courts in making that determination. As will be seen, see note 41 infra and text accompanying notes 40$41,66-68$ infra, some courts specifically refuse to take into account certain of these factors. 
1. Assertions by the Claimant. An individual's claim that his beliefs or activities are religious is unquestionably an important factor to be considered by the court; the real question is how important is the claimant's own characterization of his beliefs. At one extreme are those who argue that the individual's claim should be the sole factor in determining whether his belief is religious. ${ }^{35}$ The Supreme Court has taken a more moderate position, terming the claimant's representation of his belief as religious "highly relevant," 36 "the central consideration" 37 and a factor that "must be given great weight." 38 It remains uncertain, however, what legal effect these selfcharacterizations have, that is, whether a person's claim that his belief is religious goes so far as to create a rebuttable presumption of the belief's religiousness or whether it is merely one of several factors to be considered by the court. ${ }^{39}$

2. Time of Acquisition of Belief. The courts are split as to whether the time of the acquisition of the belief should be taken into consideration in determining whether the belief is religious. The relevance which some courts accord to the "age" of a belief can probably be attributed to two overlapping factors. The first is the human tendency of judges to mistakenly rely upon easily discernible facts, such as the length of time a belief has been held, in attempting to determine the existence or nonexistence of undefinable metaphysical concepts such as religion. The second is confusion on the part of the courts between what should be two distinct determina-

35. "[W]e can only know that a claim is based on religion when we are told it is . . . What a man presents as a religious claim . . . cannot be attacked." Weiss, supra note 24 , at 604,605 , quoted in part in Founding Church of Scientology v. United States, 409 F.2d 1146, 1161 n.52 (D.C. Cir.), cert. denied, 396 U.S. 963 (1969); accord, Galanter, supra note 22, at 264. But see Malnak v. Yogi, 440 F. Supp. 1284, 1304-05 (D.N.J. 1977) (subjective characterizations by individuals cannot be determinative of whether or not teachings are religious within meaning of first amendment); United States v. Kuch, 228 F. Supp. 439, 443 (D.D.C. 1969) (mere adoption of religious nomenclature insufficient to invoke protection of first amendment); Giannella, Religious Liberty, Nonestablishment, and Doctrinal Development-Part I. The Religious Liberty Guarantee, 80 HARV. L. REV. 1381, 1419 (1967) (claimant's own assessment of religious importance of his claim cannot always be taken at face value). For the related argument that courts cannot define "religion" without violating the first amendment, see note 24 supra.

36. Welsh v. United States, 398 U.S. 333, 341 (1970) (plurality opinion).

37. Id. at 339.

38. United States v. Seeger, 380 U.S. 163, 184 (1965). The Court's inquiry centered upon "whether a given belief . . . occupies a place in the life of its possessor parallel to that filled by the orthodox belief in God of one who clearly qualifies for the exemption." Id. at 165-66. See 91 HARV. L. REv. 879, 882 n.31 (1978) (highly subjective and personal nature of religion dictates that determination of whether belief is religious be exceedingly deferential).

39. Cf. Founding Church of Scientology v. United States, 409 F.2d 1146 (D.C. Cir.), cert. denied, 396 U.S. 963 (1969) (court held that Church had established prima facie case of its status as a religion and since the government did not contest such status the Church was entitled to first amendment protection). 
tions: whether a particular belief is religious and whether the belief is sincere. The length of time a belief has been held goes to the sincerity of the belief rather than to the religious nature of the belief. ${ }^{40}$ Thus, the trier of fact is more likely to find that a belief is sincerely held if, in the case of an individual, the claimant has expressed the belief all his life or, in the case of an institution, the belief has been a doctrine of the institution throughout its history. In contrast, where the belief has been recently adopted under circumstances indicating that the exigencies of the situation were more responsible for its adoption than was a true religious experience, the fact finder is likely to discount the sincerity of that belief. While this line of reasoning may be proper for determining the sincerity with which a belief is held, the first amendment protects all religious beliefs regardless of their date of origin. ${ }^{41}$ Nonetheless, courts do sometimes seize upon the length of time a belief has been held as evidence of whether or not the belief is religious. ${ }^{42}$

In light of the foregoing, the fact that Dade Christian's policy of denying admission to blacks had only developed over the preceding ten to fifteen years ${ }^{43}$ should not be viewed by the court as indicating that the underlying belief was not religious in nature. ${ }^{44}$

3. Source of the Belief. The source of the claimant's belief is often a major factor in determining whether it is religious. Thus, persons who are

40. See note 71 infra and accompanying text.

41. Malnak v. Yogi, 440 F. Supp. 1284, 1315 (D.N.J. 1977) (new religions cannot stand outside first amendment merely because they did not exist when the Bill of Rights was drafted); Stevens v. Berger, 428 F. Supp. 896, 900 (E.D.N.Y. 1977) (one person's religious beliefs held for one day are presumptively entitled to the same protection as the beliefs of millions which have been shared for thousands of years).

42. See, e.g., Brown, slip op. (Findings of Fact and Conclusions of Law) at 4 (philosophy which evolves from 1961 to 1973 does not constitute that type of sincerely held fundamental religious belief which is protected by free exercise clause).

The Supreme Court does not seem to have adopted a firm position on this issue. In Wisconsin v. Yoder, 406 U.S. 205 (1972), the Court specifically relied upon the long history (nearly 300 years) of the Amish faith and way of life as one of several factors in determining that the Amish's refusal to send their children to public or private schools after the eighth grade was firmly grounded in their central religious beliefs. Id. at 216-17, 219. Yet in both United States v. Seeger, 380 U.S. 163 (1965), and Welsh v. United States, 398 U.S. 333 (1970), where neither of the claimants had adopted pacifist views at the time of their registration for the draft, see Welsh, 398 U.S. at 336, the Court found that both claimants held beliefs entitling them to exemption from the draft as "religious" conscientious objectors.

43. Slip op. (Findings of Fact and Conclusions of Law) at 4.

44. Although the Brown plurality acknowledged that "a religious belief may be of recent vintage or formed instantaneously," $556 \mathrm{~F} .2 \mathrm{~d}$ at 313 , it held that there was ample evidence to support the trial judge's conclusion that "if belief in school segregation was religious in nature, neither the officers of the school nor the congregation of the church were aware of it." Id. Compare Brown with Bob Jones Univ. v. Johnson, 396 F. Supp. 597 (D.S.C. 1974), aff'd mem., 529 F.2d 514 (4th Cir. 1975), where the court noted that the university's religious belief that the Bible forbids racial intermarriage had been held since the university's inception in 1929. 
members of established religions ${ }^{45}$ or who claim individualized beliefs derived from well-known religious authorities, such as the Bible, ${ }^{46}$ are more likely to be found by the courts to hold religious beliefs than are persons who have no extrinsic basis for their beliefs. ${ }^{47}$ The only recent Supreme Court decisions concerning the source of a belief and its relevancy to whether the belief is religious are United States $v$. Seeger ${ }^{48}$ and Welsh $v$. United States. ${ }^{49}$ These cases involved determinations of whether persons claiming exemption from combatant training and military service were conscientiously opposed to participation in war in any form "by reason of religious training and belief," as required by section $6(j)$ of the Universal Military Training and Service Act. ${ }^{50}$ The Welsh Court held, in a plurality opinion, 51 that a person's conscientious objection to all war is "religious"

45. See, e.g., Wisconsin v. Yoder, 406 U.S. 205 (1972) (Old Order Amish); Sherbert v. Verner, 374 U.S. 398 (1963) (Seventh-Day Adventist Church); Braunfeld v. Brown, 366 U.S. 599 (1960) (Judaism); Follett v. Town of McCormick, 321 U.S. 573 (1944) (Jehovah's Witnesses); Reynolds v. United States, 98 U.S. 145 (1878) (Church of Jesus Christ of Latter-Day Saints (Mormon Church)); Bob Jones Univ. v. Johnson, 396 F. Supp. 597 (D.S.C. 1974), aff'd. mem., 529 F.2d 514 (4th Cir. 1975) (Christianity); Unitarian Church West v. McConnell, 337 F. Supp. 1252 (E.D. Wis. 1972), aff'd mem., 474 F.2d 1351 (7th Cir. 1973), vacated on other grounds, 416 U.S. 932 (1974) (Unitarian Church).

46. See, e.g., Wisconsin v. Yoder, 406 U.S. 205 (1972); West Virginia Bd. of Educ. v. Barnette, 319 U.S. 624 (1943); Stevens v. Berger, 428 F. Supp. 896 (E.D.N.Y. 1977); Bob Jones Univ. v. Johnson, 396 F. Supp. 597 (D.S.C. 1974), aff'd mem., 529 F.2d 514 (4th Cir. 1975).

47. This "preference" of the courts for beliefs which are a part of an established religion or which are based upon historical literature such as the Bible borders upon being an unconstitutional establishment of religion in violation of the first amendment. The establishment clause prohibits the government from preferring one religion over another. Everson v. Board of Educ., 330 U.S. 1, 15 (1947). By giving preferential treatment to a claimant who is a member of an established religion or who derives his beliefs from the Bible, the courts in effect prefer these types of religious beliefs over other, less widely accepted religions.

48. 380 U.S. 163 (1965).

49. 398 U.S. 333 (1970).

50. 62 Stat. 612 (1948) (current version at 50 U.S.C. app. \$ 456(j) (Supp. V 1975)). At the time of the decisions in Seeger and Welsh, the statute stated: "Religious training and belief in this connection means an individual's belief in a relation to a Supreme Being involving duties superior to those arising from any human relation, but does not include essentially political, sociological, or philosophical views or a merely personal moral code." Compare this language with Chief Justice Hughes' dissent in United States v. Macintosh, 283 U.S. 605, 633 (1931), overruled on other grounds, Girouard v. United States, 328 U.S. 61 (1946). See note 22 supra.

In 1967 Congress amended section $6(j)$ to eliminate the requirement of a belief in a Supreme Being, probably as a result of the Court's decision in Seeger. Pub. L. No. 90-40, 81 Stat. 104 (1967) (codified at 50 U.S.C. app. § 456(j) (Supp. V 1975)).

51. The Court's opinion in Welsh, written by Justice Black, was joined by Justices Douglas, Brennan and Marshall. Justice Harlan concurred in the result and adopted the plurality's test of whether a belief is "religious" within the meaning of section 6(j); however, whereas the plurality's opinion was based upon statutory construction, Justice Harlan concluded that section 6(j)'s requirement of "theistic beliefs runs afoul of the religious clauses of the First Amendment." 398 U.S. at 345. Justice Harlan nevertheless adopted the plurality's test and concurred in the result "as the touchstone for salvaging a congressional policy of long standing that would otherwise have to be nullified." Id. 
within the meaning of section $6(j)$ if it stems from the person's deeply and sincerely held "moral, ethical, or religious beliefs about what is right and wrong and [if] these beliefs [are] held with the strength of traditional religious convictions." 52 Thus, "beliefs that are purely ethical or moral in source and content" would be considered "religious" if they met the other requirement of the Court's test. ${ }^{53}$

Seeger and Welsh significantly broadened the meaning of the phrase "religious belief." 54 Simultaneously, the two decisions blurred the distinction between beliefs based upon secular considerations and beliefs based upon sectarian considerations. Although the secular/sectarian dividing line had never been clear-cut, ${ }^{55}$ and notwithstanding that these cases primarily involved only questions of statutory interpretation, Seeger and Welsh manifested the Court's willingness to extend the area of judicial protection to activities and beliefs which, while not "confined in either source or content to traditional or parochial concepts of religion, . . . occupy . . . 'a place parallel to that filled by ... God' in traditionally religious persons." 56 In view of this extremely liberal interpretation of the phrase

52. Id. at $339-40$.

53. Id. at 340. Accord, Gillette v. United States, 401 U.S. 437, 439 (1971). The defendant in Gillette, who had been convicted of failure to report for induction into the armed forces, held beliefs "based on a humanist approach to religion." Id. The Court held that there was no doubt as to the religious character of the beliefs, but it affirmed the conviction because the defendant based his conscientious objection on the "unjust nature" of the Vietnam War, rather than upon "war in any form" as required by section 6(j). However, in Wisconsin v. Yoder, 406 U.S. 205 (1972), the Court stated that "philosophical and personal" beliefs are not religious and are not protected by the free exercise clause. Id. at 215 . This departure from the Welsh language was noted by Justice Douglas in his dissent in Yoder. 406 U.S. at 247-49.

54. See note 25 supra and accompanying text.

55. See note 24 supra and text accompanying notes 22-24 supra for a review of the difficulties courts have had in attempting to define "religion."

56. Welsh, 398 U.S. at 339-40 (quoting Seeger, 380 U.S. at 166).

In United States v. Kuch, 288 F. Supp. 439 (D.D.C. 1968), the defendant in a prosecution for the possession and sale of illegal drugs claimed to be an ordained minister in the NcoAmerican Church and argued that the prosecution was an infringement of the free exercise of her religion. The court held that the Church was not a bona fide religious institution and that the defendant had not sustained her burden of demonstrating that her religious beliefs required her to ingest psychadelic drugs. To be exempted from the proscriptions imposed by public laws, according to the court, the defendant must produce evidence of a belief in "a supreme being, a religious discipline, a ritual, or tenets to guide one's daily existence." Id. at 444. Although the Church had an official handbook containing its principles and doctrines, the court found it to be "full of goofy nonsense, contradictions, and irreverent expressions." Id. at 444-45. The court essentially found the Church and the free exercise claim to he a facade, stating that the Church membership mocked established institutions and that any efforts to assert attributes of religion were "only for tactical purposes." Id.

The California Supreme Court reached the opposite conclusion in People v. Woody, 61 Cal. 2d 716, 40 Cal. Rptr. 69, 394 P.2d 813 (1964), holding that the use of peyote by an Indian tribe was in bona fide pursuit of their religious faith. The court stated that the defendants, members of the Native American Church, used peyote as a sacramental symbol similar to the use of bread and wine in Christian churches, but added that to Native American Church 
"religious belief," a court would be quite justified in finding that Dade Christian's belief that the Bible ${ }^{57}$ forbids the commingling of whites and blacks under circumstances which may tend to promote interracial marriage is, at least for purposes of this case, a religious belief. Likewise, a claimed religious belief in the practice of racial segregation on the part of other private sectarian schools, even if not purportedly stemming from Biblical sources, might well be considered a belief entitled to first amendment protection.

4. Written Documentation. Courts occasionally cite the existence of writings documenting and corroborating a claimed religious belief ${ }^{58}$ in support of their determination that the belief is religious. ${ }^{59}$ Although such evidence is relevant with respect to that determination, the existence of a writing is certamly not essential to a finding that a belief is entitled to first amendment protection; many courts have held beliefs to be religious in the absence of any such documentary evidence. ${ }^{60}$ The best approach probably is

members, peyote was more than a sacrament and constituted, in itself, an object of worship. 61 Cal. 2d at 721, $40 \mathrm{Cal}$. Rptr. at 73, 394 P.2d at 817. The court was also impressed that Church members considered the use of peyote for nonreligious purposes sacrilegious.

Kuch and Woody are reconcilable, although Woody is definitely a minority view; most courts confronting the issue of a free exercise defense to prosecutions for drug offenses have held that the drugs were not used for religious purposes. See Annot., 35 A.L.R.3d 939 (1971) (Free Exercise of Religion as Defense to Prosecution for Narcotic or Psychadelic Drug Offense) (cases and commentaries collected). The Kuch court held that to be exempted from the proscriptions of drug laws, the defendant must produce evidence of a religious discipline or ritual. That is precisely what the Woody defendants did by showing that their use of peyote was a ritual comparable to the communion in Christian churches. Their religious discipline was evidenced by the fact that the Indians advocated the use of peyote only for religious purposes; they considered any other usage sacrilegious.

57. Dade Christian's policy of racial exclusion was based on "the overall concept of the teachings of the Scriptures," 556 F.2d at 320, and upon "God's will." Id. Compare Brown with Yoder, Barnette, and Stevens (claimants' beliefs based upon specific section or passage of Bible). Testimony indicated that the claimants in Brown believed that racial integration of Dade Christian would constitute "disobedience to God." Id. at 319.

58. A writing documenting a claimed religious belief is to be distinguished from the source of a claimant's belief, as discussed in the text accompanying notes $45-57$ supra. In the latter case, the writing serves as a general origin or basis of the belief, while in the former, it is merely evidence of, not authority for, the belief.

59. See, e.g. , Founding Church of Scientology v. United States, 409 F.2d 1146 (D.C. Cir.), cert. denied, 396 U.S. 963 (1969) (Church's Creed and fundamental writings introduced in evidence in support of Church's contention that it is a religion entitled to protection of first amendment).

60. See, e.g., Wisconsin v. Yoder, 406 U.S. 205 (1972) (refusal to send children to school past eighth grade); West Virginia State Bd. of Educ. v. Barnette, 319 U.S. 624 (1943) (refusal to salute American flag); Cantwell v. Connecticut, 310 U.S. 296 (1940) (selling religious books door-to-door); Teterud v. Burns, 522 F.2d 357 (8th Cir. 1975) (prisoner's insistence upon wearing long braided hair); People v. Woody, 61 Cal. 2d 716, 40 Cal. Rptr. 69, 394 P.2d 813 (1964) (use of peyote).

In Bob Jones Univ. v. Johnson, 396 F. Supp. 597 (D.S.C. 1974), aff'd mem., 529 F.2d 514 (4th Cir. 1975), the university's policy of denying admission to unmarried nonwhites and 
that the existence of a writing or of documentary evidence may be considered as corroboration of a claim that a particular belief is religious, and consequently may give the claimant a stronger case, but that its absence may not be taken into account as a factor negating the religious claim. Following this reasoning, the fact that Dade Christian's list of nine tenets entitled "We believe" made no mention of commingling or separation of the races, which the Brown plurality found to be "strong evidence" of the lack of a religious basis for the school's racially discriminatory admission policy, ${ }^{61}$ should not be considered by the court as indicating that the school's segregationist belief is not religious in nature. This, in fact, was the position of a majority of the Brown court. ${ }^{62}$

5. Importance of the Belief. The relative importance of a particular belief with respect to the claimant's religion is a factor that has been considered by some courts in determining whether a particular belief is religious. Thus, the court in People v. Woody ${ }^{63}$ emphasized that peyote plays "a central role" in the ceremony and practice of the Native American Church. ${ }^{64}$ The Supreme Court in Seeger indirectly indicated that the signifi-

expelling students who dated members of any race other than their own was not set forth in the university's corporate charter, by-laws, catalogues or other publications, even though the other basic precepts of the university were published therein. Nevertheless, the court found that the university's policy was a religious belief based upon Biblical interpretation.

The plaintiffs in Stevens v. Berger, 428 F. Supp. 896 (E.D.N.Y. 1977), believed that if their children were to obtain social security numbers their spiritual well-being and chance to enter Heaven would be seriously jeopardized. The court held that this was a religious belief entitled to first amendment protection notwithstanding that the plaintiffs had no writings documenting their belief and that the belief was derived from an individualized interpretation of the Bible.

61. Although the plurality acknowledged that "[w]e do not hold that a belief must be permanently recorded in written form to be religious in nature," $556 \mathrm{~F} .2 \mathrm{~d}$ at 312 , it stated: "[T]he absence of references to school segregation in written literature stating the church's belief, distributed to members of the church and the public by leaders of the church and administrators of the school, is strong evidence that school segregation is not the exercise of religion." Id. Similarly, the trial judge noted that Article Three of Dade Christian's Articles of Incorporation made no reference to any fundamental religious tenet or conviction concerning commingling of the races: "The membership of this corporation shall consist of any and all competent persons of good moral character who sympathize with and in good faith wish to participate in the purposes and objects herein expressed." Slip op. (Findings of Fact and Conclusions of Law) at 5 (emphasis added). The plurality found it significant that the onc writing that did declare that blacks would not be admitted to the school, viz. the card handed to Mrs. Brown, see text accompanying note I1 supra, stated that the practice of racial exclusion was based upon policy. 556 F.2d at 312 .

The existence or nonexistence of documentary evidence of the belief may be considered in determining the sincerity of the belief. See text accompanying note 72 infra.

62. Concurring Judge Goldberg and the six dissenting judges agreed that "a religious practice does not have to be written to enjoy First Amendment protection." 556 F.2d at 325 .

63. 61 Cal. 2d 716, 40 Cal. Rptr. 69, 394 P.2d 813 (1964).

64. Id. at 720, 40 Cal. Rptr. at 73, 394 P.2d at 817. See also LaReau v. MacDougall, 473 F.2d 974, 979 (2d Cir. 1972), cert. denied, 414 U.S. 878 (1973) (forbidding segregated prisoner 
cance of a belief to the claimant's religion may have some bearing upon the determination of whether a belief is religious. ${ }^{65}$

Other courts, however, have refused to examine the importance of a particular belief or activity with respect to the claimant's religion, arguing that such an examination is equivalent to the court's determining religious orthodoxy in violation of the first amendment. ${ }^{66}$ If courts were to require that a particular belief be an "absolute tenet" or an "integral part" of a religion in order to qualify for first amendment protection as a religious belief, then the courts would be, in effect, controlling the structure of religions. Such judicial preoccupation and interference with the nature of religious beliefs would result in excessive government entanglement with religion and would almost certainly violate both the establishment clause ${ }^{67}$ and the free exercise clause. ${ }^{68}$ Consequently, the fact that Dade Christian's practice of maintaining racial separation in activities that constitute "socialization" may be only a minor part of its religion, while going to the weight to be accorded the religious belief, should not be considered by the court in determining whether the belief is religious.

from attending mass not a violation of his freedom of religion because of overriding importance of maintaining peace and order within prison).

65. 380 U.S. at 184. Cf. Brown, slip op. (Findings of Fact and Conclusions of Law) at 11 (school's segregation policy not a "fundamental" religious practice); 91 HARV. L. REV., 879, $880 \mathrm{n.9}$ (1978) (trial judge in Brown strongly implied that he required religious belief to be "fundamental" in order to be within protection of first amendment).

66. Unitarian Church West v. McConnell, 337 F. Supp. 1252 (E.D. Wis. 1972), aff'd mem., 474 F.2d 1351 (7th Cir. 1973), vacated on other grounds, 416 U.S. 932 (1974) (court rejected state's argument that teaching of sex education course as part of church's Sunday school program was not intertwined with the "basic" tenets of the religion; issued motion for preliminary injunction enjoining prosecution for violation of state obscenity laws); Teterud v. Burns, 522 F.2d 357, 360 (8th Cir. 1975) (court rejected argument that prisoner must prove that wearing long braided hair was "an absolute tenet" of Indian religion). The Teterud court stated: "Proof that the practice is deeply rooted in religious belief is sufficient. It is not the province of government officials or court to determine religious orthodoxy." Id. See also Fowler v. Rhode Island, 345 U.S. 67 (1953) (ordinance prohibiting member of Jehovah's Witnesses from making speech in public park violates first amendment); United States v. Ballard, 322 U.S. 78 (1944), rev'd on other grounds, 329 U.S. 187 (1946) (first amendment bars court from questioning truth or falsity of claimed religious beliefs); West Virginia State Bd. of Educ. v. Barnette, 319 U.S. 624 (1943) (student may not be required to salute American flag in contravention of his religious belief).

67. For related discussions of how subconscious "preferences" of courts and "religious exemptions" from géneral secular laws may violate the establishment clause, see note 47 supra and note 97 infra, respectively. See also note 113 infra.

68. Notwithstanding the inappositeness of considering the relative importance of a belief with respect to the claimant's religion for the purpose of determining whether the belief is religious, it is a legitimate factor to be considered in determining whether the claimant's first amendment rights are outweighed by an opposing state interest. See text accompanying notes 114-16 infra. 


\section{Sincerity of the Belief.}

The final issue to be resolved concerning a private sectarian school's claimed religious belief is whether it is truly and sincerely held. ${ }^{69}$ Because this is a relatively clear-cut question of fact, ${ }^{70}$ it has not been the source of as much trouble or confusion for the courts as the more ambiguous inquiry into whether a belief is religious. Among the factors considered by courts in determining the sincerity of the belief are the time of and the circumstances surrounding the acquisition of the belief, ${ }^{71}$ the existence or nonexistence of

69. United States v. Seeger, 380 U.S. 163, 185 (1965) ("the threshold question of sincerity . . . must be resolved in every case"); United States v. Ballard, 322 U.S. 78 (1944), rev'd on other grounds, 329 U.S. 187 (1946) (court may determine whether defendants in mail fraud prosecution held claimed religious beliefs in good faith but may not question veracity of beliefs). Contra, Sheldon v. Fannin, 221 F. Supp. 766, 775 (D. Ariz.), appeal dismissed per curiam, 372 U.S. 228 (1963) (school board enjoined from suspending students who refused to stand for singing of national anthem on account of their religious beliefs) ("the sincerity or reasonableness of this claim may not be examined by this or any other Court'); see Ballard, 322 U.S. at 93-95 (Jackson, J., dissenting) (first amendment prohibits courts from examining claimant's subjective commitment to his belief). The Sheldon court clearly confused the question of the sincerity and reasonableness of a religious belief. It correctly cited Ballard, Cantwell and Reynolds for the proposition that the reasonableness of a religious belief cannot be questioned, but nowhere do those or any other cases state that testing the sincerity of a belief is beyond the purview of the courts. Justice Jackson's argument is evaluated in Giannella, supra note 35, at 1418. Cf. Sherbert v. Verner, 374 U.S. 398, 407 (1963), in which the court lcft open the question whether any consideration of the sincerity of a belief was foreclosed by Ballard's prohibition against judicial inquiry into the truth or falsity of religious beliefs.

One commentator has argued that the question of the sincerity of the belief is composed of two distinct determinations: first, whether the claimant is truthful in asserting that he adheres to the practice at issue and, second, whether he adheres to it for the reasons he alleges. 91 HaRv. L. REV., 879, 882 \& n.28 (1978).

70. See, e.g., United States v. Seeger, 380 U.S. 163, 185 (1965) (question of sincerity of belief is one of fact); Theriault v. Carlson, 495 F.2d 390, 394 (5th Cir.), cert. denied, 419 U.S. 1003 (1974). However, it has been pointed out that the sincerity with which a belief is held by an individual "is a subjective state of mind which does not lend itself easily to proof or disproof." Note, Racial Discrimination in Private Schools, Section 1981, and the Free Exercise of Religion: The Sectarian Loophold of Runyon v. McCrary, 48 U. CoL. L. Rev. 419, 429(1977). Nevertheless, the courts have had ample experience dealing with subjective states of mind in a wide variety of criminal and civil cases; triers of fact are presumed proficient at finding whether a person does or does not possess a particular state of mind. See text accompanying notes 71-75 infra for an enumeration of factors used in making this determination.

71. Courts in several cases have held that the time of, and the circumstances surrounding, the acquisition of a belief may be a factor, although not necessarily decisive, in determining sincerity. In Maguire v. Wilkinson, 405 F. Supp. 637 (D. Conn. 1975), the court held that a prison regulation extending the right to wear beards only to those prisoners holding religious beliefs requiring the wearing of beards who had beards at the start of incarceration violated the first amendment rights of a prisoner whose sincere religious belief was acquired subsequent to his incarceration. Although the court refused to permit such a presumption of insincerity based upon the time of acquisition, it did state that "the fact that thee claimed religious belief was not held prior to incarceration and was espoused somewhat precipitiously" could be given "some weight" in determining the sincerity of a claimed religious belief. Id. at 640 .

Courts considering the claims of military servicemen asserting the right to discharge as "religious" conscientious objectors have held that the timing of the servicemen's applications 
documentary evidence of the belief, ${ }^{72}$ the presence of inconsistencies between the claimant's statements and conduct, ${ }^{73}$ the mental or physical costs which the claimant is willing to endure ${ }^{74}$ and the claimant's demeanor on the witness stand. 75

The sincerity of the belief underlying Dade Christian's policy of racial exclusion was essentially not in dispute in Brown; the district court stated that "[t]here is no doubt that it is a sincerely held belief and the Court

for conscientious objector status is a factor that may be considered in testing the sincerity of their religious belief. See, e.g., Smith v. Laird, 486 F.2d 307 (10th Cir. 1973) (inference of insincerity created by physician's application for conscientious objector discharge on same day that he was sworn into Air Force after completing medical internship negated by explanation that his beliefs had been developing prior to swearing in); Rothfuss v. Resor, 443 F.2d 554 (5th Cir. 1971) (timing of application for conscientious objector discharge on eve of deployment to combat zone may be considered by Army in determining sincerity of belief but in itself is not sufficient basis for rejection of prima facie showing of conscientious objection); Speer v. Hedrick, 419 F.2d 804 (9th Cir. 1969) (completion of instruction in use of deadly weapons and receipt of orders to combat zone before application for discharge as conscientious objector supported finding of adequate basis in fact for denial of application).

72. Although the nonexistence of documentary evidence of the belief may not be used as a factor justifying a finding that the belief is not entitled to first amendment protection, see text accompanying notes 60-61 supra, it is a relevant and permissible factor to be considered in determining the sincerity of the belief.

73. See, e.g., Witmer v. United States, 348 U.S. 375 (1955), in which the defendant, who had been convicted of failing to submit to induction into the armed forces, had applied for an agricultural classification as a farmer and had expressly disclaimed any ministerial exemption. Upon the denial of this application, he requested classification as a minister, claiming to be a member of Jehovah's Witnesses. The Court held that the inconsistencies between the defendant's statements to his draft board and his conduct was one of several factors casting doubt upon the sincerity of his claim. See also Dobkin v. District of Columbia, 194 A.2d 657,659 (D.C. 1963) (claimant's free exercise rights not violated by trial on his Sabbath where evidence showed that he regularly worked on that day).

74. In Stevens v. Berger, 428 F. Supp. 896 (E.D.N.Y. 1977), the plaintiffs were welfare recipients who refused to obtain social security numbers for their children, claiming that to do so would violate their religious beliefs. Because of this refusal, the State of New York discontinued the plaintiffs' welfare payments. The plaintiffs then instituted an action seeking injunctive and declaratory relief. In holding that the plaintiffs' beliefs were sincerely held, the court stated that the following testimony of the plaintiffs' pastor summed up the matter: "I believe their beliefs are sincere and I don't believe they would have gone through all this if they were not." Id. at 901.

In In re Jenison, 267 Minn. 136, 125 N.W.2d 588, vacated and remanded per curiam, 375 U.S. 14 (1963), the relator was found guilty of contempt for refusing on religious grounds to serve as a juror. Although unable to suggest any specific guidelines for ascertaining whether a particular belief is being invoked with sincerity, the court held that the relator "has convincingly demonstrated her sincerity by preferring jail to the compromise of her religious faith." 267 Minn. at 137,125 N.W.2d at 590.

75. "[T] $]$ he sincerity of an individual's free exercise claim is determinable in much the same way as is credibility-from demeanor and consistency as perceived by reasonable persons." Note, supra note 27, at 253; see Stevens v. Berger, 428 F. Supp. 896, 901 (E.D.N.Y. 1977) (court's observation of plaintiffs during trial one of factors considered in determining that their belief was sincerely held). 
recognizes the sincerity." 76 Although the plurality attempted to impeach that sincerity by noting the recent adoption of the school's discriminatory policy during a period of increased school integration and the absence of any writings documenting the religious basis for the belief, 77 the dissenting judges concluded that the record did not show any attempt to adopt religious nomenclature merely to shield the school's admission policy from the application of section $1981 .^{78}$

Understandably, judges and juries may find it difficult to believe that anybody could interpret the Bible as commanding racial segregation or barring racial intermarriage. United States $v$. Ballard ${ }^{79}$ and subsequent cases, however, have made clear that courts cannot examine the truth, reasonableness, rationality or morality of religious beliefs. Unfortunately, while this may be an admirable goal in theory, in practice it is difficult, if not impossible, to achieve. ${ }^{80}$ As one commentator stated, "inquiry into the

76. Slip op. (Findings of Fact and Conclusions of Law) at 8, quoted by Judge Roney, dissenting, 556 F.2d at 325 .

77. The latter three factors used in ascertaining the sincerity of a belief, see text accompanying notes 73-75 supra, are not especially useful in the case of Dade Christian. The school did not make any statements inconsistent with its conduct, the fact that the school was willing to go to court to defend its admission policy does not significantly indicate the sincerity with which the underlying belief is held and, since the case was tried solely on the basis of depositions and documentary evidence, there were no live witnesses whose credibility the trial judge could evaluate. However, any or all of these factors could be applicable in the case of a different private sectarian school that denied admission to blacks.

78. $556 \mathrm{~F} .2 \mathrm{~d}$ at 325.

79. 322 U.S. 78 (1944), rev'd on other grounds, 329 U.S. 187 (1946). In a frequently quoted passage, Justice Douglas wrote:

The religious views espoused by [the defendants] might seem incredible, if not preposterous, to most people. But if those doctrines are subject to trial before a jury charged with finding their truth or falsity, then the same can be done with the religious beliefs of any sect. When the triers of fact undertake that task, they enter a forbidden domain.

322 U.S. at 87-88. Accord, United States v. Seeger, 380 U.S. 163, 184-85 (1965) (courts may not reject beliefs as not being religious because they consider them "incomprehensible").

80. "As might be expected, one can discern in the pattern of decisions certain judicial predispositions which reflect the predominant western religious tradition of our culture." Giannella, supra note 35, at 1419. See id. at 1385 (Supreme Court has followed a course "that ultimately intimates a judicial approval of established orthodox values" and prefers prevailing morality over religious liberty of radical dissenters). Judge Goldberg perceptively related this problem to the facts in Brown:

Had the church members read the Bible and sought to obey God in a more conventional fashion, their views would have passed unquestioned as "religious." Yet the only distinction between such clearly "religious" views and those now before the court would lie in their familiarity to the majority of our citizens and to the judges of this court. If such a distinction determined one's ability even to cross the threshold to have one's free exercise claims heard on their merits, first amendment jurisprudence would indeed be at a low ebb.

$556 \mathrm{~F} .2 \mathrm{~d}$ at 320 .

Cf. An Act for Establishing Religious Freedom, Ch. XX, 1794 Va. Acts 32, 32 (1785) (12 Hening's 84, 85 (1823)) (current version at VA. CODE § 57-1 (1974)):

[T]hat to suffer the civil magistrate to intrude his powers into the field of opinion, and 
good faith of a religious belief seldom can be uninfluenced by one's views as to its truth." 81 Not surprisingly, courts will rarely admit to any such inherent bias, but its existence may be seen in the courts' evaluations of different religions. Thus, the Supreme Court in Wisconsin v. Yoder ${ }^{82}$ examined in detail Amish practices and way of life and came to the unstated but implicit conclusion that the Amish culture, though perhaps "alien," was based upon reasonable beliefs and was an admirable attempt to recreate life in an earlier, simpler time. ${ }^{83}$

\section{Close Cases: Giving Religion the Benefit of the Doubt.}

The question of whether Dade Christian's denial of admission to blacks is the exercise of religion is a very close one. ${ }^{84}$ The district court and the Fifth Circuit plurality made convincing arguments, supported by the factual record, that the school's policy of racial discrimination reflected the secular philosophy of the officers, patrons and members of the parent church. Judge Goldberg and the six dissenting judges, comprising a majority of the court of appeals, persuasively contended, with comparable evidentiary support, that Dade Christian and the affiliated individuals held a sincere religious belief forbidding commingling of blacks and whites under circumstances which may, in their view, tend to promote interracial marriage. It should be noted that, notwithstanding the difficulty of deciding this issue under the facts in Brown, cases could arise involving private sectarian schools holding beliefs identical to that claimed by Dade Christian in which the facts would clearly demonstrate the religious nature of the belief; in other cases where

to restrain the profession or propagation of principles on supposition of their ill tendency, is a dangerous fallacy, which at once destroys all religious liberty, because he being of course judge of that tendency will make his opinions the rule of judgment, and approve or condemn the sentiments of others only as they shall square with or differ from his own....

(Emphasis added).

81. D. MANWARING, supra note 24 , at 51 . Justice Jackson, in his dissenting opinion in Ballard, also recognized this problem: "[A]s a matter of either practice or philosophy I do not see how we can separate an issue as to what is believed from considerations as to what is believable." 322 U.S. at 92.

82. 406 U.S. 205 (1972).

83. 406 U.S. at 209-13. Cf. Stevens v. Berger, 428 F. Supp. 896 (E.D.N.Y. 1977), in which the court became involved in an extensive scholarly analysis of western theology and the New and Old Testaments in an attempt to justify its conclusion that the plaintiffs' belief that the use of social security numbers was a device of the Antichrist was a religious belief. Id. at 903-05. Although the court acknowledged at the onset that "[n]o finding as to the historical accuracy and theological soundness of these plaintiff' contentions are made since such judgments . should be avoided by the courts," id. at 902-03, it found that "[t]he evidence does support plaintiffs' contention that there is some arguable theological basis for their beliefs." Id. at 903. The court determined, in effect, that the claimed belief was a reasonable theological interpretation of the Bible and was therefore a religious belief.

84. The plurality acknowledged that the facts could have supported a finding by the trial court that the school's policy constituted the exercise of religion. 556 F.2d at 312 n.4. 
such beliefs have been claimed as justification for the exclusion of blacks from an educational institution ${ }^{85}$ and a business establishment, ${ }^{86}$ courts have not hesitated to assume that the practices based upon these beliefs constituted the exercise of religion under the first amendment.

Nevertheless, the courts need some basis for deciding close cases in which the claimed religious belief could legitimately be classified as either secular or sectarian. Accordingly, where the evidence is ambiguous but sufficient to support a finding that a given belief is religious in nature, the preferred position historically accorded freedom of religion requires that the claimant be given "the benefit of the doubt," for it is constitutionally preferable to mistakenly treat as religious a belief based upon secular considerations than to deny first amendment protection to a truly religious belief. ${ }^{87}$ In cases such as Brown, where both parties are claiming fundamental constitutional rights, ${ }^{88}$ "[i]t is extremely important that religion be defined in such a manner that labeling does not become the touchstone of constitutional analysis." 89

\section{BalanCING THE INTERESTS: THE SCHOOL'S Right to THE FREE EXERCISE OF RELIGION VERSUS THE GOVERNMENT'S INTEREST IN Prohibiting Racial Discrimination}

Once a court has determined that a private school's policy of racial exclusion is based upon religious beliefs protected by the free exercise clause of the first amendment, it is presented with the problem of deciding whether the school's free exercise claim is a legally sufficient defense to the plaintiffs' claim under section 1981. Because section 1981 was enacted

85. Bob Jones Univ. v. Johnson, 396 F. Supp. 597 (D.S.C. 1974), aff'd mem., 529 F.2d 514 (4th Cir. 1975) (university held "deep religious belief" that Bible forbids intermarriage of races and exercised this belief by denying admission to unmarried nonwhites and expelling students dating members of any race other than their own). See text accompanying notes 171-72 infra.

86. Newman v. Piggie Park Enterprises, Inc., 256 F. Supp. 941 (D.S.C. 1966), rev'd on other grounds, 377 F.2d 433 (4th Cir. 1967), aff'd per curiam, 390 U.S. 400 (1968) (restaurant owner claimed religious belief compelling him to oppose any integration of the races whatever). See text accompanying note 157 infra.

87. "[B]ecause in safeguarding conscience we are dealing with interests so subtle and so dear, every possible leeway should be given to the claims of religious faith." Minersville School Dist. v. Gobitis, 310 U.S. 586, 594 (1940). (Although the Gobitis Court violated this principle in upholding a student's expulsion for refusing to salute the American flag pursuant to his religious belief, this decision was shortly thereafter overruled in West Virginia Bd. of Educ. v. Barnette, 319 U.S. 624 (1943)). "Court opinions abound in citations aimed to show that mistakes in the area of religious freedom have far worse consequences for the whole public than damage to its secular interests arising from a too meticulous protection of religion." E. SMITH, RELIGIOUS LIBERTY IN THE UNITED STATES 325 (1972). Judge Goldberg in Brown also emphasized the need to define "religion" broadly: "We must be clear beyond the peradventure of anyone's speculation that what is religion is given its place as religion." $556 \mathrm{~F} .2 \mathrm{~d}$ at 317 .

88. See text accompanying note 90 infra.

89. Brown, 556 F.2d at 317 (Goldberg, J., specially concurring). 
pursuant to Congress' power under section two of the thirteenth amendment, ${ }^{90}$ lawsuits of this nature are in reality constitutional conflicts between the schools' first amendment right to the free exercise of religion and Congress' thirteenth amendment power to identify and eliminate the badges and incidents of slavery. In order for courts to decide which of these two opposing interests is to prevail, it is necessary to analyze the nature and scope of each.

\section{A. Distinction Between Freedom of Conscience and Freedom to Act.}

Freedom of conscience, which includes the freedom to believe, has been protected as an absolute right throughout American history from precolonial times. ${ }^{91}$ Yet, since the seventeenth century, it has been consistently recognized that the functioning of an orderly society requires that a distinction be drawn between freedom of conscience and freedom to act pursuant to conscience and that, under certain circumstances, an individual's right to practice his religion may be restricted or regulated by the state..$^{92}$

90. Runyon v. McCrary, 427 U.S. 160, 170 (1976) (quoting Jones v. Alfred H. Mayer Co., 392 U.S. 409, 440 (1968)). See note 6 supra and authorities cited therein.

91. See authorities cited in note 92 infra.

92. The first official declaration expressly withdrawing the absolute protection accorded freedom of conscience from acts inimical to society was the charter of Rhode Island and the Providence Plantations granted by King Charles II in 1663. 6 THE Federal AND STATE Constitutions, Colonial Charters, and Other Organic laws 3211, 3213 (F. Thorpe ed. 1909); The Charter Granted by His Majesty, King Charles II of Rhode Island and ProvidencePlantations, at 4-5 (Samuel Hall printer 1767) (modern spelling).

The first amendment, the contemporary bulwark of freedom of conscience, went through several different versions before it reached the familiar form which became part of the Constitution. Each of the earlier versions made specific reference to the "rights of conscience," indicating an intent on the part of the drafters to protect freedom of conscience, but not freedom to act pursuant to conscience. I ANNALS OF CoNGress 434, 435, 729 (Gales ed. 1834). Although these references were dropped in the final wording and were replaced by the free exercise clause, there is no evidence to indicate that Congress thereby intended to make any substantive change in the effect of the amendment. No mention was made during the congressional debates of any intent to protect actions taken pursuant to religious beliefs. Supporting this view of the scope of the first amendment's religion clauses is the statement of Oliver Ellsworth, a member of the Constitutional Convention and later Chief Justice of the Supreme Court:

But while I assert the rights of religious liberty, I would not deny that the civil power

has a right, in some cases, to interfere in matters of religion. It has a right to prohibit and punish gross immoralities and impieties; because the open practice of these is of evil example and detriment.

Connecticut Courant, Dec. 17, 1787, quoted in Braunfeld v. Brown, 366 U.S. 599, 603 n.2 (1960) (emphasis supplied by Court) (plurality opinion), and 1 A. STOKES, CHURCH AND STATE IN THE UNITED STATES 535 (1950). For a discussion of the legislative history of the first amendment, see the following articles in 14 LAW \& CONTEMP. PROB. (1949) (Religion and the State): Corwin, The Supreme Court as National School Board, 3, 11; Fahy, Religion, Education, and the Supreme Court, 73, 79; Murray, Law or Prepossessions?, 23, 41-43; Sullivan, Religious Education in the Schools, 92, 105-06.

The language ultimately adopted in the first amendment was partially derived from the historic Virginia Declaration of Rights, Ch. I, § 16, 1794 Va. Acts 3 (1776) (9 Hening's Stat. 109 
The leading modern case recognizing this distinction is Cantwell $v$. Connecticut, ${ }^{93}$ in which the defendants had been convicted of inciting a breach of the peace and of violating a state statute prohibiting the solicitation of money for alleged religious, charitable or philanthropic causes without the approval of a state official. The defendants, members of Jehovah's Witnesses, had gone door-to-door attempting to sell religious books. The Supreme Court unanimously reversed the convictions, holding that the statute as construed and applied violated the defendants' freedom of reli-

(1821)) (current version at VA. CoNST. art. I, § 16 (1973)), which guaranteed all men "the free exercise of religion, according to the dictates of conscience." $1794 \mathrm{Va}$. Acts at 4 (9 Hening's Stat. at 111-12). The Virginia legislature subsequently enacted a second landmark in the history of American religious freedom-An Act For Establishing Religious Freedom, Ch. XX, 1794 Va. Acts 32 (1785) (12 Hening's Stat. 84 (1823)) (current version at VA. CoDE § 57-1 (1974)). Written by Thomas Jefferson, the act recognized an explicit distinction between beliefs and overt acts and recognized the right of government to interfere with antisocial acts. The preamble of the act provides:

[T] hat to suffer the civil magistrate to intrude his powers into the field of opinion, and to restrain the profession or propagation of principles on supposition of their ill tendency, is a dangerous fallacy, which at once destroys all religious liberty. . . .

[T] hat it is time enough for the rightful purposes of civil government, for its officers to interfere when principles break out into overt acts against peace and good order. . . .

1794 Va. Acts at 32 (12 Hening's Stat. at 85) (emphasis added). The Supreme Court in Reynolds v. United States, 98 U.S. 145 (1878), quoted the preamble and commented: "In these two sentences is found the true distinction between what properly belongs to the church and what to the State." Id. at 163. Jefferson elaborated on the belief/action distinction in his Notes oN VIRGINIA: "The legitimate powers of government extend to such acts only as are injurious to others. But it does me no injury for my neighbor to say there are twenty gods, or no God. It neither picks my pocket nor breaks my leg." T. JefFERSON, NOTES ON VIRGINIA, Query XVII, in 2 THE WRITINGS OF ThOMAS JEFFERSON 221 (A. Bergh ed. 1907). Government has no power over rights of conscience or belief, said Jefferson. "Reason and free inquiry are the only effectual agents against error. Give a loose to them, they will support the true religion by bringing every false one to their tribunal, to the test of their investigation." Id. See generally id. 217-25.

Many of the original state constitutions, while including provisions for the preservation of religious freedom and freedom of conscience, specifically left unprotected acts which disturb the peace, endanger public health of safety, or infringe the rights of others. E.g. GA. CONST. of 1777 , art. LVI (current version at GA. CONST. art. 1, §§ 2-102 to 103) ("All persons whatever shall have the free exercise of their religion; provided it be not repugnant to the peace and safety of the state"); The Declaration of Rights, $1787 \mathrm{Md}$. Laws 112 (Nov. 3, 1776) (Kilty's Stat. cl) (current version at MD. CONST., Declaration of Rights, art. 36) ("no person ought by any law to be molested in his person or estate on account of his religious persuasion or profession, or for his religious practice, unless under color of religion any man shall disturb the good order, peace or safety of the state, or shall infringe the laws of morality, or injure others in their natural, civil or religious rights") (emphasis added); N.H. CONST. part I, art. S) ("Every individual has a natural and unalienable right to worship God according to the dictates of his own conscience, and reason ... provided he doth not disturb the public peace or disturb others in their religious worship" "); N.Y. CONST. of 1777, art. XXXVIII (current version at N.Y. CONST., art. 1, § 3) ("the free Exercise and Enjoyment of religious Procession and Worship, without Discrimination or Preference, shall forever hereafter be allowed within this State to all mankind. Provided, That the Liberty of Conscience hereby granted, shall not be so construed, as to excuse Acts of Licentiousness, or justify practices inconsistent with the Peace or Safety of this State") (emphasis supplied). See generally FREEDOM OF RELIGION (E. Gotthelf ed. 1941) (compilation of historical documents relating to freedom of religion).

93. 310 U.S. 296 (1940). 
gion. However, the Court analyzed the first amendment as having a double aspect: the amendment guarantees, first, freedom of conscience and freedom to adhere to the religious organization of one's choice and, second, the free exercise of religion. ${ }^{94}$ " Thus the Amendment embraces two conceptsfreedom to believe and freedom to act. The first is absolute but, in the nature of things, the second cannot be. Conduct remains subject to regulation for the protection of society." 95

\section{B. Formulating the Balancing Test.}

The fact that government has the constitutional power to regulate and, at times, to prohibit activities, even when conducted pursuant to a sincere religious belief, does not mean that all religious practices are within the province of governmental control; it means only that the first amendment does not absolutely protect such activities. The free exercise clause clearly does provide a substantial amount of constitutional protection for certain types of religiously-based behavior. ${ }^{96}$ The court's task in each case is to determine whether the first amendment protects a particular type of behavior and, if so, to what extent. ${ }^{97}$ This determination necessarily requires the

94. Id. at 303.

95. Id. at 303-04 (footnote omitted), quoted in School Dist. of Abington Twp. v. Schempp, 374 U.S. 203, 218 (1963) (Bible reading in public schools violates establishment clause of first amendment), and United States v. Ballard, 322 U.S. 78, 86 (1944), rev'd on other grounds, 329 U.S. 187 (1946) (defendants convicted of mail fraud despite claim that allegedly fraudulent misrepresentations were statements of religious belief); accord, Braunfeld $\mathrm{v}$. Brown, 366 U.S. 599 (1961) (state statute prohibiting Sunday retail sale of certain enumerated commodities does not unconstitutionally infringe free exercise rights of Orthodox Jews whose faith required them to close their businesses and totally abstain from all manner of work from nightfall Friday until nightfall Saturday).

96. [O]ur decisions have rejected the idea that religiously grounded conduct is always outside the protection of the Free Exercise Clause . . . But to agree that religiously grounded conduct must of ten be subject to the broad police power of the State is not to deny that there are areas of conduct protected by the Free Exercise Clause of the First Amendment and thus beyond the power of the State to control, even under regulations of general applicability.

Wisconsin v. Yoder, 406 U.S. 205, 219-20 (1972).

97. The establishment clause of the first amendment imposes limits upon governmental aid to religion. In order for private sectarian schools which deny admission to blacks on the basis of a religious belief to be exempted from the application of section 1981, the courts would have to find that such judicial action does not foster the establishment of religion. The Supreme Court has acknowledged that there is a "danger that an exception from a general obligation of citizenship on religious grounds may run afoul of the Establishment Clause." Wisconsin v. Yoder, 406 U.S. 205, 220-21 (1972); see Gillette v. United States, 401 U.S. 437, 452 (1971); Welsh v. United States, 398 U.S. 333, 373-74 (1970) (White, J., dissenting); Arlan's Dep't Store Inc. v. Kentucky, 371 U.S. 218, 220 (1962) (per curiam) (Douglas, J., dissenting). See generally Galanter, supra note 22 , at $288-95$. The Court, however, has simultaneously stated that the danger of violating the establishment clause "cannot be allowed to prevent any exception no matter how vital it may be to the protection of values promoted by the right of free exercise." Yoder, 406 U.S. at 221. See Welsh v. United States, 398 U.S. 333, 358 n.9 (1970) (Harlan, J., concurring); School Dist. of Abington Twp. v. Schempp, 374 U.S. 203, 295 (Brennan, J., concurring). 
courts to balance the claimant's interest in the free exercise of religion against the government's interest in the challenged policy or statute. ${ }^{98}$ Although the Supreme Court has employed a balancing test in recent free exercise cases, these decisions have created some confusion concerning the conclusiveness to be given the governmental interest in the balancing process.

The two similar yet distinct methods of treating the governmental interest are illustrated by comparing the Court's opinions in Sherbert $v$.

In virtually every case in which this issue has arisen, the Court has held that legislative and judicial exemptions for religious activities from the requirements of general secular laws do not constitute the establishment of religion. Thus, the Yoder Court, utilizing a "sensible and realistic" application of the religion clauses, found that exempting the Amish from strict compliance with a state mandatory school attendance law did not violate the establishment clause. The Court noted that the three main concerns against which the establishment clause sought to protect were the "sponsorship, financial support, and active involvement of the sovereign in religious activity." " 406 U.S. at 234 n.22 (quoting Walz v. Tax Commission, 397 U.S. 664, 668 (1970)). Accommodating the Amish's religious beliefs, according to the Court, merely allowed their centuries-old religious society to survive and "reflects nothing more than the governmental obligation of neutrality in the face of religious differences, and does not represent that involvement of religious with secular institutions which it is the object of the Establishment Clause to forestall." " 406 U.S. at 234 n.22 (quoting Sherbert v. Verner, 374 U.S. 398, 409 (1963)). See, e.g., Gillette v. United States, 401 U.S. 437 (1971) (exemption from draft for persons conscientiously opposed to war by reason of religious training and belief does not constitute establishment of religion); Walz v. Tax Commission, 397 U.S. 664 (1970) (tax exemption for real property owned by religious associations and used exclusively for religious purposes is not unconstitutional as an attempt to establish, sponsor or support religion); People v. Woody, 61 Cal. 2d 716, 727 n.9, 40 Cal. Rptr. 69, 77 n.9, 394 P.2d 813, 821 n.9 (1964) (determination that members of Native American Church are entitled to "religious exemption" from drug laws "raises no issue under the Establishment Clause"). The Court's past decisions indicate that when an individual's or a group's free exercise rights are found to entitle the claimant to exemption from the requirements of a general statute, the Court is not likely to hold that such an exemption violates the establishment clause.

98. See, e.g., Wisconsin v. Yoder, 406 U.S. 205 (1972); Sherbert v. Verner, 374 U.S. 398 (1963); Marsh v. Alabama, 326 U.S. 501 (1946); Stevens v. Berger, 428 F. Supp. 896 (E.D.N.Y. 1977). However, Justice Douglas in his dissenting opinion in McGowan v. Maryland, 366 U.S. 420 (1961), stated:

There is in [the First Amendment religious beliefs] realm no room for balancing. I see no place for it in the constitutional scheme. . . . The religious regime of every group must be respected-unless it crosses the line of criminal conduct. But no one can be forced to come to a halt before it, or refrain from doing things that would offend it. Id. at 575. Note, however, that even those commentators who advocate the strict and absolute separation of church and state concur with the necessity of performing a balancing test of the opposing interests. See, e.g., L. Pfeffer, supra note 24, at 611-18. See generally Giannella, supra note 35, at 1389-90; Kauper, supra note 32, at 845-46.

A private sectarian school could assert rights other than the right to the free exercise of religion as a defense to an action under section 1981. Among other possible defenses would be the freedom of association and privacy and a parent's right to direct the education of his children. If asserted, these defenses would theoretically be combined with the freedom of religion on the balance scale opposing the governmental interest. The Court in Runyon, however, held that section 1981 as applied did not violate any of these additional rights; they consequently do not affect the balancing process. 427 U.S. at 175-79. See note 7 supra and text accompanying notes 175-76 infra. 
Verner $^{99}$ and Wisconsin v. Yoder. ${ }^{100}$ The first step in both cases was to determine whether application of the statute or policy in question actually abridged or imposed a burden upon the free exercise of the claimant's religion. ${ }^{101}$ Having found such an abridgment or burden, the Court expressed the second determination differently in the two decisions. The Sherbert Court stated that the abridgment of free exercise rights could be justified only by a "compelling state interest." 102 Under this formulation of the test, if a court found that the government had a compelling interest in prohibiting private sectarian schools from denying admission to blacks, then the plaintiffs in a section 1981 action would automatically prevail, even if the school's interest in the free exercise of its religion were exceptionally compelling. ${ }^{103}$ In contrast, the Yoder Court stated that for the state to deny the free exercise of religious belief there must be "a state interest of sufficient magnitude to override the free exercise clause." 104 This "ad hoc" approach requires the court to examine the particular facts in each case and to weigh the interest of the government in outlawing the practice of racial discrimination by private sectarian schools against the interest of the school in the free exercise of its religion, thereby providing a means of determining whether governmental interference with religious freedom is justified under the circumstances. ${ }^{105}$

99. 374 U.S. 398 (1963).

100. 406 U.S. 205 (1972).

101. 406 U.S. at 214; 374 U.S. at 403.

102. 374 U.S. at 403,406 (quoting NAACP v. Button, 371 U.S. 415,438 (1963)). Cf. United States v. O'Brien, 391 U.S. 367,377 (1968) (statute prohibiting knowing destruction or mutilation of draft cards furthers substantial governmental interest and does not violate draft card burner's freedom of expression).

103. See Marcus, The Forum of Conscience: Applying Standards Under the Free Exercise Clause, 1973 DuKE L.J. 1217, 1245. See generally Nimmer, The Right to Speak From Times to Time: First Amendment Theory Applied to Libel and Misapplied to Privacy, 56 CAL. L. REv. 935, $942-48$ (1968).

104. 406 U.S. at 214.

105. See Clark v. Holmes, 474 F.2d 928, 931 (7th Cir. 1972), cert. denied, 411 U.S. 972 (1973); Marcus, supra note 103, at 1239-40; cf. Pickering v. Board of Educ., 391 U.S. 563, 568 (1968) (teacher dismissed for writing and publishing letter criticizing Board of Education) (court must balance interests of teacher in commenting upon matters of public concern and interest of state in promoting efficiency of public services); Barenblatt v. United States, 360 U.S. 109, 126 (1958) (defendant convicted for refusing to answer questions of congressional subcommittee) (courts must balance first amendment right of freedom of association against public interest). But of. Zwickler v. Koota, 389 U.S. 241, 268 n.20 (1967) (action for declaratory judgment and injunction against future criminal prosecution for violation of statute by distributing anonymous political handbills) (balancing of government's interest in national security, expressed by criminal statute, and individual's first amendment rights inappropriate). The "ad hoc" type balancing test was well described by Justice Frankfurter in his opinion in McGowan v. Maryland, 366 U.S. 420 (1961):

If the value to society of achieving the object of a particular regulation is demonstrably outweighed by the impediment to which the regulation subjects those whose religious practices are curtailed by it, or if the object sought by the regulation could with equal 
The compelling interest test is clearly the simpler of the two approaches because it allows the court effectively to ignore the weight of the free exercise claim; so long as the state or, as in Brown, a private plaintiff asserting the state's interest, ${ }^{106}$ can satisfy the necessary threshold showing, the court need go no further. ${ }^{107}$ Unfortunately, this advantage of the compelling state interest test is its very shortcoming. By avoiding a close examination of the school's free exercise interest, that is, by not ascertaining such relevant factors as the importance of the disputed practice to the religious belief and the probable consequences of an adverse decision upon the religion, the court fails to accord the school's first amendment rights the full degree of judicial protection to which they are entitled.

Concededly, the pure "ad hoc" balancing approach is based upon the consideration of factors relevant only to the specific case being decided and consequently is of limited value in creating precedents for future free exercise cases. ${ }^{108}$ The compelling state interest test, on the other hand, has the advantage of enabling courts, at least to a limited extent, to base their decisions "upon standards or principles which transcend the particular fact situation involved." ${ }^{109}$ But the desirability of establishing a uniform legal standard should not be allowed to override a claimant's right to a comprehensive scrutiny and weighing of his free exercise claim before the court makes its decision. Consequently, the application of section 1981 to a private sectarian school with a religiously motivated discriminatory admis-

effect be achieved by alternative means which do not substantially impede those religious practices, the regulation cannot be sustained.

Id. at 462. For a discussion of possible alternative means of regulation in cases such as Brown, see text preceding note 142 infra.

Although it could reasonably be argued that the quotation from the Yoder opinion, see text accompanying note 104 supra, does not propose a pure case-by-case "ad hoc" balancing of the governmental and religious interests, the Yoder Court nevertheless examined the Amish religion at great length and concluded that the Amish religious interests and practices were entitled to great weight. Thus, even though the Court agreed that the state had a substantial interest in compulsory school attendance, it determined that the Amish free exercise rights outweighed the state's interest. Compare Yoder with Sherbert, where the Court was concerned primarily with the absence of a compelling state interest in denying unemployment compensation to Sabbatarians rather than with the substantiality of the free exercise claim.

106. While it may seem anomalous for private black citizens to advocate what is essentially an argument on behalf of the government, the circumstances surrounding cases such as Brown undoubtedly justify this procedure. Since the plaintiffs' cause of action is based upon section 1981 and the gist of the school's defense is that the statute cannot be constitutionally applied to it, the private plaintiffs must be allowed to assert the government's interest in applying section 1981 to private sectarian schools because the alternative would be the dismissal of the case.

107. See Marcus, supra note 103 , at 1242.

108. See id. at 1240. See also Nimmer, supra note 103, at 939.

109. Marcus, supra note 103, at 1232; see Nimmer, supra note 103, at 939; cf. New York Times Co. v. Sullivan, 376 U.S. 254 (1964) (Court establishes "knowing or reckless disregard of falsity" standard for libel cases). 
sion policy should be analyzed under a pure balancing test that takes into account all relevant interests. ${ }^{110}$

\section{Elements of the Balancing Test.}

The first element of the Sherbert-Yoder two-part test-whether the government's regulation infringes the free exercise of religion-is rarely a major factor per se in free exercise cases. Typically, the government concedes that its legislative measure imposes a burden upon the claimant's religious practice, but contends that the imposition is justified by an important state interest. ${ }^{111}$ Certainly this is true in the case of a private sectarian school whose religious belief prohibits socialization between races under circumstances which may lead to racial intermarriage. Forcing such schools to admit black students would clearly violate their religious tenets and would thereby impose a burden upon the free exercise of their religion. Consequently, the focus shifts to the essence of the balancing test-whether the government has a sufficiently strong interest in the elimination of the practice of racial discrimination by private sectarian schools to justify the infringement of the school's free exercise rights. ${ }^{112}$ The three main elements affecting the outcome of the balancing process are the importance of the religious interest, the importance of the governmental interest and the degree of interference with the claimant's practice of religion caused by the governmental regulation. ${ }^{113}$

110. See Marcus, supra note 103, at 1240 . Even though the court's analysis of free exercise cases should not consist solely of a determination of whether the state has a compelling interest in the regulation of a religious activity, this does not mean that the existence or nonexistence of such a compelling state interest is irrelevant to the court's inquiry. Because the Yoder test involves a balancing of the state's interest against the claimant's interest, the nature and magnitude of the governmental interest is highly germane; indeed a determination of the scope of the governmental interest is a prerequisite to the actual balancing. If the state's interest in prohibiting the practice of racial discrimination by private sectarian schools is found to be "compelling," then the school's free exercise interest would need to be much stronger in order to defeat a section 1981 action than if the state's interest carried less weight.

111. See, e.g., Wisconsin v. Yoder, 406 U.S. 205 (1972); Gillette v. United States, 401 U.S. 437 (1971); Sherbert v. Verner, 374 U.S. 398 (1963); Braunfeld v. Brown, 366 U.S. 599 (1961); Prince v. Massachusetts, 321 U.S. 158 (1944); Martin v. City of Struthers, 319 U.S. 141 (1943). At this point in the Court's inquiry, the degree of the infringement caused by the governmental regulation is irrelevant; that determination plays a role only in the actual balancing of the governmental and religious interets. See text accompanying notes 117-22 infra. Here the only question is whether or not there is any infringement of the free exercise of religion. Once that minimum threshold level of interference has been reached the Court proceeds to balance the respective interests.

112. See Giannella, supra note 35 , at 1390 (critical element in religious liberty cases is assessment of governmental interest).

113. The number of persons who actually or can potentially lay claim to the religious belief for which special protection is sought may also be a factor taken into account by the courts in determining whether the governmental regulation unduly inf ringes the claimant's free exercise of religion. L. PFEFFER, supra note 24, at 616; see Note, supra note 70, at 432 \& n.69; Note, 
1. Importance of the Religious Interest. The determination of the importance of a particular religious practice may be viewed as a measurement of the degree to which the practice is central, essential or integral to the claimant's religion. ${ }^{114}$ Courts have consistently been more willing to

supra note 27, at 257. This factor has at least two aspects. First, the purpose of the Bill of Rights was to protect minorities who might otherwise be at the mercy of a hostile majority in control of the government. "The smaller the minority, the more likely it is to need constitutional protection; the greater it is, the more likely it is to obtain the protection it needs through legislative exemption rather than judicial intervention." L. PFEFFER, supra note 24, at 616. Following this reasoning, courts would feel an obligation to weigh the free exercise interests of minority religions more heavily than the claims of widely accepted religions. See, e.g., Wisconsin v. Yoder, 406 U.S. 205 (1972), in which the Court noted that the Amish, clearly a minority group, would be forced to leave Wisconsin in order to practice their religion in the face of a compulsory school attendance law. Id. at 218 n.9. See also Cantwell v. Connecticut, 310 U.S. 296 (1940), and the subsequent line of cases involving distribution of literature and solicitation of sales by Jehovah's Witnesses, a classic minority group; People v. Woody, 61 Cal. 2d 716, 40 Cal. Rptr. 69, 394 P.2d 813 (1964) (Native American Church, a socially and politically powerless group). Unquestionably, any religion which teaches the necessity of racial segregation would be in a minority and thus would qualify for "special protection" from the courts.

Second, the governmental interest is more likely to be seriously jeopardized if a large number of persons demand exemption from the application of general laws than if only a small minority group requests exemption. This consideration was incorporated into a test by Justice Frankfurter, concurring in Douglas v. Jeannette, 319 U.S. 157 (1943):

A common-sense test as to whether the Court has struck a proper balance of [the individual's right of the free exercise of religion and society's rights] is to ask what the effect would be if the right given to these [claimants] should be exercised by all sects and denominations.

Id. at 180. Moreover, as noted by Judge Goldberg in Brown, judicial recognition of a free exercise defense to section 1981 actions on the part of private sectarian schools would likely result in numerous fraudulent and exaggerated religious claims by private segregated schools attempting to avoid compulsory desegregation under Runyon. 556 F.2d at 323-24. This would force courts to either undermine Runyon by recognizing most such claims or to draw fine distinctions between religions, thereby subjecting the courts to possible establishment clause violations due to excessive government entanglement with religion. Id. See text accompanying note 67 supra.

The number of potential claimants was a significant consideration in the Court's decision in Sherbert. The state asserted an interest in assuring that enough money remained in the unemployment compensation fund to support all the claims against it and in assuring that employers were not seriously hindered in scheduling necessary work. Clearly, both these interests are directly dependent upon the number of persons claiming exemption from a state regulation denying benefits to persons who refuse to work on Saturdays. See Clark, Guidelines for the Free Exercise Clause, 83 HARv. L. Rev. 327, 332 \& n.29 (1969). But see Sherbert, 374 U.S. at $420 \mathrm{n} .2$ (Harlan, J., dissenting), discussed in Clark, supra, at 332-33. The Court noted that only two of the 150 or more Seventh-Day Adventists in the area had been unable to find suitable non-Saturday employment, 374 U.S. at $399 \mathrm{n} .2$, and held that the asserted state interests were outweighed by the burden imposed upon the claimant's free exercise of religion. It is not inconceivable that in a city populated primarily by Seventh-Day Adventists in which only Saturday work was available, the Court would have weighted the governmental interest more heavily as against the religious claim of Sabbatarians.

114. Note that while the importance of a religious practice does play a role in the assessment of the weight to be given the practice, it is not a factor in determining whether a belief is religious. See text accompanying notes 66-68 supra. However, judicial determinations as to whether a particular practice is "central" to a religion, even if only for purposes of balancing the governmental and free exercise claimant's interests, may raise issues similar to those 
weigh heavily free exercise claims involving practices found to be within the "core" of a religion than claims involving practices at the "periphery." 115

It is conceivable that a private sectarian school could adhere to a religion based solely upon the belief that there can be no socialization between the races whatsoever. Clearly, since the belief in racial segregation would be the only tenet of such a faith, it would necessarily be central and essential to the religion. In such an extreme case, the school's free exercise interest in being exempted from the application of section 1981 would be very substantial. In the more typical case, however, such as in Brown, the school's belief in racial segregation is likely to be only a peripheral aspect of its religious doctrine. In fact, one of Dade Christian's officers testified that the practice of maintaining racial separation in activities constituting "socialization" was only a "very minor" part of the supporting church's religion. ${ }^{116}$ This fact would tend to diminish the weight attached to Dade Christian's free exercise claim when balanced against the state's interest in eliminating the practice of racial discrimination. The school's claim is further weakened by the fact that its policy of racial exclusion, rather than stemming directly from a belief against commingling of the races, was essentially only an indirect means of fulfilling the alleged Biblical command to eschew racial intermarriage.

2. Interference with the Religious Practice. The second primary factor used in determining the weight of a free exercise claim is the extent and degree of interference with the religious practice caused by the governmental regulation. ${ }^{117}$ This factor was stressed in several cases, most notably

discussed earlier with respect to the courts' capacity and ability to fairly determine what beliefs are entitled to first amendment protection. See Galanter, supra note 22, at 277-78; Giannella, supra note 35 , at 1385 . See note 47 supra and accompanying text.

115. See, e.g., Wisconsin v. Yoder, 406 U.S. 205, 218 (1972) ("basic religious tenets and practices"); Sherbert v. Verner, 374 U.S. 398, 406 (1963) ("cardinal principle"); Murdock v. Pennsylvania, 319 U.S. 105 (1943); People v. Woody, 61 Cal. 2d 716, 40 Cal. Rptr. 69, 394 P.2d 813 (1964); L. TRIBE, supra note 22, \$ 14-11; Galanter, supra note 22, at 274-77.

116. 556 F.2d at 321 .

117. The Sherbert Court found that the state's denial of unemployment compensation clearly interfered with the free exercise of the claimant's religion, even though the burden may have been only indirect and even though no criminal sanctions directly compelled the claimant to work six days per week. 374 U.S. at 403 . But see Braunfeld v. Brown, 366 U.S. 599 (1961), in which the Court determined that the state's Sunday Closing Law as applied to the claimants was only an "indirect burden on the exercise of religion" operating so as to make the practice of their religious beliefs more expensive but not in itself illegal. Id. at 606. Other examples of "indirect burdens," according to the Court, are income taxes on individuals preventing them from giving more money to churches and the closing of courts on weekends imposing a burden on attorneys whose religion requires them to re'st on weekdays. The Court expressly stated, however, that whether a statute results in economic disadvantage to some religious sects is not an absolute test for determining whether the statute violates the free exercise clause. Id . at 60607. The direct/indirect comparison should be inconsequential in the case of a private sectarian 
in Yoder. The Yoder Court found that the state's compulsory school attendance law compelled the Amish "to perform acts undeniably at odds with fundamental tenets of their religious beliefs" and "carrie[d] with it a very real threat of undermining the Amish community and religious practice."118 Similarly, in People v. Woody, ${ }^{119}$ the court stated that enforcing the statutory prohibition against the use of peyote would result in "virtual inhibition of the practice of defendants' religion." 120 By comparison, requiring private sectarian schools such as Dade Christian to admit blacks would not have as devastating an impact upon the claimant's religion as did application of the state laws in Yoder and Woody. Although application of section 1981 would directly violate the school's religious tenets, ${ }^{121}$ the resulting interference with religious freedom would be slight since the segregationist beliefs are not an important part of the school's overall religious doctrine. ${ }^{122}$ Accordingly, while the interference with the practice of the school's religion unquestionably constitutes an "infringement" of the free exercise of religion sufficient to justify a balancing of the school's first amendment rights against the governmental interest expressed by section 1981 , the total adverse impact upon the religion as a whole is so negligible that courts would not be likely to weigh the school's interest very heavily.

3. The Governmental Interest. The nature and magnitude of the government's interest in enforcing a statute or policy without creating exceptions for a particular individual or group is often the crucial factor in freedom of religion balancing tests. Regardless of the weight accorded a specific religious practice on the basis of the facts in each case, the first amendment requires that, at the very least, the government regulation must further an important or substantial governmental interest to justify the infringement of a private sectarian school's practice of religion. ${ }^{123}$ The

school which is forced by section 1981 to admit blacks in contravention of its religion. However extensive and severe the interference with the school's free exercise of religion may be, it is clearly direct, rather than indirect, interference.

118. 406 U.S. at 218.

119. 61 Cal. 2d 716, 40 Cal. Rptr. 69, 394 P.2d 813 (1964).

120. Id. at 722,40 Cal. Rptr. at 74,394 P.2d at 818 .

121. $556 \mathrm{~F} .2 \mathrm{~d}$ at 318,319 .

122. "Moreover, if it were found that the belief underlying the practice was one against intermarriage rather than against all social commingling, then the practice would be merely a discretionary means of implementing that belief and thus entitled to less weight." 91 HARV. L. REV., 879, 885 (1978). See text following note 116 supra. Of course, in the extreme case discussed in the text following note 115 supra, requiring the school to admit blacks in violation of the school's sole and fundamental religious doctrine would clearly result in a far greater degree of interference than in the case of a more typical school such as Dade Christian.

123. See United States v. O'Brien, 391 U.S. 367, 377 (1968). "Where fundamental claims to religious freedom are at stake, . . . we must searchingly examine the interests that the State seeks to promote. . . and the impediment to those objectives that would flow from recognizing the claimed [religious] exemption." Yoder, 406 U.S. at 221. 
Supreme Court has made clear that "only those interests of the highest order and those not otherwise served can overbalance legitimate claims to the free exercise of religion." 124 Consequently, unless the government can show that its interest in a particular regulation of a religious practice exceeds considerations of mere administrative convenience, the claimant's free exercise rights will automatically prevail. ${ }^{125}$ If the plaintiffs can satisfy three threshold criteria by proving that the enactment of section 1981 was within Congress' constitutional power, that the statute furthers a substantial or important governmental interest and that the incidental restriction of the school's freedom of religion is not greater than is essential to the furtherance of that interest, ${ }^{126}$ then the court should proceed to balance the governmental interest against the school's interest in the practice of its religion.

The first criterion is easily met: it is well settled that the enactment of section 1981 was within Congress' constitutional power under the thirteenth amendment. ${ }^{127}$ As to the second criterion, after the Supreme Court decision

124. Yoder, 406 U.S. at 215. The Court has used a variety of language to describe the magnitude of the governmental interest required to justify infringement of first amendment rights. The Court in West Virginia Bd. of Educ. v. Barnette, 319 U.S. 624 (1943), stated that first amendment rights "are susceptible of restriction only to prevent grave and immediate danger to interests which the state may lawfully protect." Id. at 639 (emphasis added), quoted in Braunfeld v. Brown, 366 U.S. 599, 611-12 (1961) (Brennan, J., concurring and dissenting); see L. PFefFer, supra note 24, at 615-16. In Sherbert the Court held that any incidental burden on the free exercise of the claimant's religion may be justified by a "compelling state interest in the regulation of a subject within the State's constitutional power to regulate," 374 U.S. at 403 (emphasis added) (quoting NAACPv. Button, 371 U.S. 415, 438 (1963)), and that "in this highly sensitive constitutional area, '[o]nly the greatest abuses, endangering paramount interests, give occasion for permissible limitation." 374 U.S. at 406 (emphasis added) (quoting Thomas v. Collins, 323 U.S. 516,530 (1945)). See generally United States v. O'Brien, 391 U.S. 367, 37677 \& nn.22-27 (1968) (compilation of descriptive terms used by the Court in prior cases); see also In re Griffiths, 413 U.S. 717, 721, $722 \mathrm{n.9}$ (1973) (listing of terms describing state interest necessary to justify adoption of a "suspect classification" in equal protection cases).

125. See, e.g., Marcus, supra note 103, at 1245; Stevens v. Berger, 428 F. Supp. 896 (E.D.N.Y. 1977) (state requirement that welfare recipients supply state with social security numbers overriden by religious belief against use of social security numbers).

126. See United States v. O'Brien, 391 U.S. 367, 377 (1968); cf. In re Griffiths, 413 U.S. 717, 721-22 (1973) (test to justify state's use of a suspect classification). It should be noted that neither O'Brien nor Griffiths provide for the "ad hoc" balancing of governmental and religious interests upon the facts in each case. See note 105 supra and text accompanying notes 104-05 supra. O'Brien, however, while involving first amendment rights, preceded Yoder by four years and the "balancing test" it poses specifically concerns government regulation of symbolic speech, not the exercise of religion. Although the Yoder decision did not purport to "overrule" the O'Brien test, it seems clear that the Yoder Court's handling of the free exercise claim in that case should control cases such as Brown. See note 105 supra. Griffiths was decided the year after Yoder but the facts and legal issues it presented-whether a state court rule restricting admission to the bar to United States citizens denies resident aliens the equal protection of the law-are sufficiently distinguishable from cases such as Brown to remove it as an obstacle to the application of "ad hoc" balancing in free exercise cases.

127. See, e.g., Runyon v. McCrary, 427 U.S. 160, 170 (1976); United States v. Harris, 106 U.S. 629,640 (1882) (dictum) (Civil Rights Act of 1866 was enacted by virtue of thirteenth 
in Runyon there can be little doubt that the government has a substantial interest in applying section 1981 to private schools. ${ }^{128}$ Although Runyon's holding was limited to nonsectarian schools, ${ }^{129}$ this governmental interest remains unchanged when a sectarian school asserts a free exercise claim as a defense to a section 1981 action. The only difference is that the courts must now determine whether the government's interest is sufficient to outweigh the opposing first amendment claim. To make this determination, however, the interests supporting extension of section 1981 to sectarian, as well as nonsectarian, private schools must be more fully analyzed.

The prohibition of racially discriminatory admission practices in private sectarian schools serves two important governmental interests. First, it furthers the integration of the public school system by reducing the likelihood of "white flight" to private segregated institutions. Second, it promotes the elimination of racial discrimination in private sectors of society.

The massive withdrawal of white children from the public schools and the concomitant establishment of segregated private school systems has been extensively documented. ${ }^{130}$ Courts have recognized that the flourishing of racially segregated private schools can seriously hinder the integration of public school systems. ${ }^{131}$ "White flight" not only creates mostly- and allblack public schools, but it also undermines financial support for public schools by way of automatic reduction of state funds due to decreased enrollment, the reduction of discretionary educational appropriations from state legislatures and local school boards, and the increasing refusal by local electorates to approve new bond issues. ${ }^{132}$ Of course, according to recent

amendment); Waters v. Wisconsin Steel Works of Int'l Harvester Co., 427 F.2d 476, 482 (7th Cir. 1970). See note 6 supra.

128. See 427 U.S. at $170-73$.

129. See note 8 supra and accomanpanying text.

130. See, e.g., Note, Section 1981 and Discrimination in Private Schools, 1976 DUKE L.J. 125, 125-26 \& nn.4, 8 and authorities cited therein; Note, Segregation Academies and State Action, 82 YALE L.J. 1436 (1973) (private segregated academies in the South "clearly threaten to frustrate the national goal of banishing racial segregation from the classroom," $i d$. at 1453); Note, supra note 70, at 419-20.

131. See, e.g. , Cook v. Hudson, 365 F. Supp. 855, 860 (N.D. Miss. 1973), aff'd per curiam, 511 F.2d 744 (5th Cir. 1975), cert. dismissed, 429 U.S. 165 (1976) ("white flight may present a serious obstacle to effective desegregation [of public schools]"). A significant factor underlying the decisions in a line of cases barring the sale of public school property to segregated private schools was that the presence of all-white private schools undermined the state's efforts to integrate its public schools. See United States v. Mississippi, 499 F.2d 425 (5th Cir. 1974); McNeal v. Tate County School Dist., 460 F.2d 568 (5th Cir.), modified on rehearing, 460 F.2d 574 (5th Cir. 1971), cert. denied, 413 U.S. 922 (1973); Wright v. City of Brighton, 441 F.2d 447 (5th Cir.), cert. denied sub nom. Hoover Academy, Inc. v. Wright, 404 U.S. 915 (1971).

132. Note, Section 1981 and Discrimination in Private Schools, 1976 DUKE L.J., supra note 130, at 126 n.9; Note, Desegregation of Private Schools: Section 1981 as an Alternative to State Action, 62 GEO. L.J. 1363, 1366 (1974); Note, Segregation Academies and State Action, 82 YALE. L.J., supra note 130 , at 1452-53. See generally Poindexter v. Louisiana Financial 
Supreme Court decisions, since this de facto segregation stemming from white flight is not the result of a discriminatory intent on the part of public officials, it is not cognizable under the fourteenth amendment. ${ }^{133}$ Nevertheless, it can be argued that, without regard to constitutional considerations, public policy favors the integration of public schools. ${ }^{134}$ Accordingly, to the extent that the application of section 1981 to private sectarian schools would eliminate a refuge for whites seeking to avoid integrated schools, an important governmental interest would be served. ${ }^{135}$

The principal governmental interest served by application of section 1981 to private sectarian schools is the elimination of racial discrimination in private sectors of society. Indeed, this interest is the very essence of section 1981. ${ }^{136}$ Numerous court decisions and the adoption of a wide variety of antidiscrimination statutes and regulations by federal, state and local governments over the past three decades have reflected an unmistakable trend toward the elimination of private, as well as public, racial discrimination. ${ }^{137}$ This modern trend has been especially evident in the field

Assistance Comm'n, 275 F. Supp. 833, 856-57 (E.D. La. 1967), aff'd per curiam, 398 U.S. 571 (1968) (system of private segregated schools presents tangible and intangible costs to state and threatens to kill hope for equal educational opportunities for black and white citizens); Note, supra note 70, at 435 \& n.92 (segregated school system endangers public school system, maintains hostility between races and perpetuates humiliation of black students (citing Brown v. Board of Educ., 347 U.S. 483, 494 (1954), as to adverse effects of segregation upon black students)).

133. See Dayton Bd. of Educ. v. Brinkman, 433 U.S. 406, 413 (1977) (citing Washington v. Davis, 426 U.S. 229, 239 (1976)); Milliken v. Bradley, 418 U.S. 717, 744-47 (1974).

134. See authorities cited in notes 137-38 infra and see accompanying text.

135. See Note, supra note 28 , at 533 (state has compelling interest in racial integration of private and parochial schools which siphon off such a large number of whites from public school system as to prevent meaningful integration of public schools); $c f$. Dixon, The Supreme Court and Equality: Legislative Classifications, Desegregation, and Reverse Discrimination, 62 CoRNell L. Rev. 494, $537 \mathrm{n} .227$ (1977) (real issue in Runyon may have been need to protect desegregation of public schools against drain to private schools).

It should be noted, however, that even if the prevention of "white flight" were theoretically a proper justification for the government to employ section 1981 to forbid private sectarian schools from denying admission to blacks, the court in a particular case would have to first ascertain whether "white flight" was occurring in that area and whether requiring local private sectarian schools to admit blacks would in any way stem the "white flight." Without the element of causation, the application of an abstract legal doctrine to a specific case would be inappropriate.

136. See Runyon v. McCrary, 427 U.S. 160, 168 (1976). In fact, rather than merely representing a national policy created by legislation and enforced by judicial decisions, section 1981 embodies the thirteenth amendment's mandate to eradicate racial inequality. See Brown, 556 F.2d at 323 (Goldberg, J., specially concurring); Note, The Expanding Scope of Section 1981: Assault on Private Discrimination and a Cloud on Affirmative Action, 90 HARV. L. REv. 412, 439 (1976) (thirteenth amendment militates for a liberal application of section 1981 in all cases where it properly applies).

137. "The policy of the Nation as formulated by the Congress in recent years has moved constantly in the direction of eliminating racial segregation in all sectors of society. This Court has given a sympathetic and liberal construction to such legislation." Runyon, 427 U.S. at 191 
of education. ${ }^{138}$ Even before Runyon, section 1981 had been applied to proscribe private racial discrimination in an increasing number of contexts, including employment, ${ }^{139}$ recreational facilities ${ }^{140}$ and hospital services. ${ }^{141}$ This expanded application of section 1981 reflects judicial recognition of the government's substantial interest in eliminating private racial discrimination.

The final criterion which a governmental regulation of free exercise rights must satisfy in order to be upheld is that the incidental restriction of freedom of religion not be greater than is necessary to the furtherance of the government's interest. Assuming that the government has an interest in prohibiting private sectarian schools from practicing racial discrimination by denying admission to blacks, there is no way that that interest could be effectively furthered without enjoining such schools from continuing their discriminatory practices. Money damages are clearly an inadequate remedy if the school is permitted to continue operating in direct contravention of the proscriptions of a statute enacted pursuant to an explicit and unambiguous grant of authority by the Constitution. Section 1981 is not so concerned with

(Stevens, J., concurring) (footnotes omitted). See authorities cited at: id. at $191 \mathrm{nn.4-5}$; Norwood v. Harrison, 413 U.S. 455, 470 n.10 (1973); Bright v. Isenbarger, 314 F. Supp. 1382, 1393 (N.D. Ind. 1970) (there is a "broad social consensus against racial discrimination not only when practiced by states but also when practiced in many types of private activities'); Note, Federal Tax Benefits to Segregated Private Schools, 68 ColuM. L. REV. 922, 947 n.130 (1968); Comment, Discrimination in Private Social Clubs: Freedom of Association and Right to Privacy, 1970 Duke L.J. 1181, 1181 nn.1, 3; cf. Railway Mail Ass'n v. Corsi, 326 U.S. 88, 98 (1945) (Frankfurter, J., concurring) (state may forbid "indulgence in racial or religious prejudice to another's hurt"), discussed in Comment, supra, at 1213.

Perhaps the epitome of the modern movement towards the elimination of all forms of racial segregation is the Model Anti-Discrimination Act. Section 502, based upon the laws of Massachusetts, New York and Pennsylvania, prohibits any educational institution, public or private, from excluding an individual seeking admission as a student because of race or color. MODEL ANTI-DisCRIMINATION ACT \$ 502 (1966 Handbook of the Nat'l Conf. of Comm'rs on Uniform State Law), quoted in Green v. Connally, 330 F. Supp. 1150,1168 n.37 (D.D.C.), aff'd mem. sub nom. Coit v. Green, 404 U.S. 997 (1971). Note that while section 503 of the Act specifically exempts religious educational institutions from the general proscription against discriminatory practices to the extent that such schools may limit admission or give preference to applicants of the same religion, sectarian schools are not exempted from the prohibition against racial discrimination. See also the Civil Rights Act of 1968 which exempts religious organizations from the Act's fair housing provisions "unless membership in such religion is restricted on account of race, color, or national origin." 42 U.S.C. § 3607 (1970), noted and discussed in Note, supra note 27, at 252 \& $n .56$ (pointing out that this provision may be unconstitutional if the restriction is dictated by the religious faith).

138. See text accompanying notes 165-74 infra. Cf. Hilton, Race, Religion, and Constitutional Restraints on Private Schools, 30 RUTGERS L. REV. 329, 377 n.248 (1977) (because public interests are so strong in field of education practice of racial discrimination should not be tolerated).

139. See Johnson v. Railway Express Agency, Inc., 421 U.S. 454 (1975).

140. See Olzman v. Lake Hills Swim Club, Inc., 495 F.2d 1333 (2d Cir. 1974); Scott v. Young, 421 F.2d 143 (4th Cir.), cert. denied, 398 U.S. 929 (1970).

141. See United States v. Medical Soc'y, 298 F. Supp. 145 (D.S.C. 1969). 
compensating blacks for injury caused by racial discrimination as it is with forbidding outright such discrimination. ${ }^{142}$ If a court were to find that the plaintiffs in a section 1981 action against a private sectarian school should prevail, the only equitable and appropriate remedy would necessarily include an order enjoining the school from denying admission to blacks on account of race. ${ }^{143}$

\section{Balancing the Constitutional Interests.}

1. Effect of Religious Practice Upon the Public. When balancing the interests of the state against the free exercise interests of individuals or institutions, invariably the first determination made by the courts is whether the religious practice affects or collides with the rights of others. ${ }^{144}$ If the claimant's religious activities are of a personal nature and in no way intrude upon the public, then courts are more likely to prohibit governmental infringement of the practice. ${ }^{145}$ But if, as is more frequently the case, other

142. See note 183 infra and accompanying text.

143. "'[T] government cannot afford [plaintiffs] their right to be free of racial discrimination in contracting without infringing [the school's] opposition to such contracts." Brown, 556 F.2d at 324 (Goldberg, J., specially concurring). Since money damages alone are an inadequate remedy, the enjoining of a private school's racially discriminatory admission policy is not barred by the requirement expressed in some Supreme Court opinions that the courts determine whether there are any less restrictive alternative means by which the state may accomplish its purpose without unduly infringing freedom of religion. See, e.g., Braunfeld v. Brown, 366 U.S. 599, 607 (1961); McGowan v. Maryland, 366 U.S. 420, 462 (1961) (opinion of Frankfurter, J.), quoted at note 105 supra.

144. The Court in West Virginia Bd. of Educ. v. Barnette, 319 U.S. 624 (1943), stated: "The freedom asserted by these [claimants] does not bring them into collision with rights asserted by any other individual. It is such conflicts which most frequently require intervention of the State to determine where the rights of one end and those of another begin." Id. at 630, quoted in Braunfeld v. Brown, 366 U.S. 599, 604-05 (1961); accord, Prince v. Massachusetts, 321 U.S. 158, 177 (1944) (opinion of Jackson, J.); see Wisconsin v. Yoder, 406 U.S. 205, 224 (1972); Weiss, supra note 24, at 608 (distinguishes between pure belief, religious action which may have public manifestations and action which is clearly public). "The simple rule, so to exercise your own rights as not to infringe on those of others, will preserve equal justice among all, promote harmony, and insure success to our schools." Decision of New York State Superintendent of Common Schools Spencer (May 13, 1839), quoted in 8 SUP'T OF Common Schools, N.Y. STATE Educ. DeP'T, ORDERS AND DeCISION 87 (1939), quoted in Engel v. Vitale, 18 Misc. 2d 659, 662, 770, 191 N.Y.S.2d 453, 460, 497 (1959), aff'd, 11 App. Div. 2d 340, 206 N.Y.S.2d 183 (1960), aff'd, 10 N.Y.2d 174, 218 N.Y.S.2d 659, 176 N.E.2d 579 (1961), rev'd on other grounds, 370 U.S. 421 (1962).

145. "Religious activities which concern only members of the faith are and ought to be free-as nearly absolutely free as anything can be." Prince v. Massachusetts, 321 U.S. 158, 177 (1944) (opinion of Jackson, J.). See, e.g., Wisconsin v. Yoder, 406 U.S. 205 (1972) (refusal of Amish parents to send children to school past eighth grade); West Virginia Bd. of Educ. v. Barnette, 319 U.S. 624 (1943) (refusal of students to salute American flag); People v. Woody, 61 Cal. 2d 716, 40 Cal. Rptr. 69, 394 P.2d 813 (1964) (use of peyote by Indians). However, in situations where the governmental interest is sufficiently important, as in the case of national security or where the religious practice violates criminal laws, constituting "victimless crimes," courts often permit the state to regulate religious activities. See, e.g., Gillette v. United States, 401 U.S. 437 (1971) (religious belief against participation in Vietnam war); 
persons are adversely affected by the claimant's activities, the courts typically weigh the government's interest in regulating the practice more heavily. ${ }^{146}$ Clearly, the action taken by a private sectarian school in refusing to admit black students has a direct effect upon other persons, namely the rejected children and their parents. In Brown, not only did Dade Christian's practice of racial exclusion prevent the Brown children from enrolling as students, but Mrs. Brown was allegedly humiliated, embarrassed, nervous and emotionally upset as a result of Dade Christian's rejection of her children's application on account of race. ${ }^{147}$ By offering its services to the general public, Dade Christian could arguably have foreseen the adverse effects its racially exclusionary admission policy might have on black students and their parents.

The fact that the schools in Runyon, notwithstanding their titular identification as "private," advertised their educational services and offered them to members of the general public was a major factor in the Court's decision to apply section I981 to "private" schools. Distinguishing the Runyon schools from "truly" private schools in which personal invitations might be sent to a number of preidentified students or where the contract between teacher and pupil would be the foundation of a close association, the Court noted that the defendant schools had placed advertisements in the "Yellow Pages" of the telephone directory and had utilized mass mailings in attempting to attract students. ${ }^{148}$ Quoting the opinion of the Fourth Circuit Court of Appeals, the Court stated:

[T]hese "schools are private only in the sense that they are managed by private persons and they are not direct recipients of public funds. Their actual and potential constituency, however, is more public than private. They appeal to the parents of all children in the area who can meet their

Reynolds v. United States, 98 U.S. 145 (1879) (practice of polygamy); United States v. Kuch, 288 F. Supp. 439 (D.D.C. 1968) (possession and sale of illicit drugs).

146. See, e.g., United States v. Ballard, 322 U.S. 78 (1944) (mail fraud); Cox v. New Hampshire, 312 U.S. 569 (1941) (parading upon public street without license); United States v. Kissinger, 250 F.2d 940 (3d Cir.), cert. denied, 356 U.S. 958 (1958) (farmer not permitted to market or use wheat beyond quota allotted by Agricultural Adjustment Act). Of course, the fact that the governmental interest is accorded greater weight does not mean that it necessarily outweighs the claimant's free exercise interest. See, e.g., Martin v. City of Struthers, 319 U.S. 141 (1943) (distributing handbills door-to-door) (free exercise right asserted but decided on grounds of freedom of speech and press); Jamison v. Texas, 318 U.S. 413 (1943) (distributing handbills on city street); Cantwell v. Connecticut, 310 U.S. 296 (1940) (solicitation of money door-to-door).

147. 556 F.2d at 311; Deposition of Plaintiff Marice Brown, summarized in Brief of Appellant, supra note 13 , at 19, 20.

Section 1981 protects blacks from the infliction of this type of tangible dignitary harm. See 91 HaRv. L. REv., 879, $886^{\circ}$ \& authorities cited at n.46 (1978). The Supreme Court in Brown v. Board of Educ., 347 U.S. 483, 494 (1954), expressly recognized the stigmatizing effect of racial segregation in public schools. See note 132 supra.

148. 427 U.S. at $172 \&$ n. 10. 
academic and other admission requirements. This is clearly demonstrated in this case by the public advertisement." 149

The public nature of the Runyon schools was evidently the basis for the Court's classifying them as "commercially operated." 150

The distinction between a "private" school offering its services generally to the public, that is, what the Court termed a "commercial" school, and a "truly private" or "noncommercial" school, was elaborated upon by Mr. Justice Powell in a concurring opinion. Mr. Justice Powell contended that while section 1981 may not restrict "private" contracts that "reflect the selectivity exercised by an individual entering into a personal relationship," it does reach certain acts of racial discrimination that are part of a "commercial relationship offered generally or widely" because such acts are "private" only in the sense that they involve no state action. ${ }^{151}$ Thus, it appears that so long as the school's racially discriminatory policy is implemented in conjunction with some bona fide "purpose of exclusiveness" by which selective offers of admission are made to particular individuals, then the offeror's associational rights would outweigh the government's interest in the elimination of racial discrimination. ${ }^{152}$

2. Subordination of First Amendment Rights. (a) Purely private racial discrimination. Although it is well settled that freedom of religion and other first amendment rights are in a "preferred position," 153 courts are split as to whether freedom of religion is preferred over other constitutionally guaranteed rights. ${ }^{154}$ Notwithstanding the willingness of some courts to

149. Id. at 172 n. 10 (quoting 515 F.2d 1082, 1089 (4th Cir. 1975)) (emphasis added).

150. 427 U.S. at 168 . There is little doubt that Dade Christian qualifies as a "commercially operated" school. With respect to Dade Christian's public advertising see note 10 supra. Indeed, the district court in Brown noted that the facts in Runyon and Brown were sufficiently similar so that all the parties had recognized that the decision in Runyon would control the issue of the application of section 1981 to private schools. Slip op. (Findings of Fact and Conclusions of Law) at 1 .

151. 427 U.S. at 189.

152. Id. at 187-89. Cf. Perkins v. New Orleans Athletic Club, 429 F. Supp. 661, 663-65 (E.D. La. 1976) (section 1981 does not compel athletic club to admit black applicant where club does not advertise membership to public, receives no government support and its members have nexus of common interest).

153. See, e.g., Marsh v. Alabama, 326 U.S. 501,509 (1946); Murdock v. Pennsylvania, 319 U.S. 105, 115 (1943); Jones v. City of Opelika, 316 U.S. 584, 608 (1942) (Stone, C.J., dissenting), rev'd on other grounds per curiam, 319 U.S. 103 (1943). But see Ullmann v. United States, 350 U.S. 422, 428 (1956) (dictum) ("As no constitutional guarantee enjoys preference, so none should suffer subordination or deletion") (fifth amendment guarantee of freedom from selfincrimination not violated by court order requiring defendant to testify under grant of immunity), quoted in Cook v. Hudson, 365 F. Supp. 855, 859 (N.D. Miss. 1973), aff'd per curiam, 511 F.2d 744 (5th Cir. 1975) (in context of first amendment right to freedom of association and fourteenth amendment rights to due process and equal protection).

154. Engel v. Vitale, 18 Misc. 2d 659, 684 n.118, 191 N.Y.S.2d 453, 481 n.118 (1959), aff'd, 11 App. Div. 2d 340, 206 N.Y.S.2d 183 (1960), aff'd, 10 N.Y.2d 174, 218 N.Y.S.2d 659, 176 N.E.2d 579 (1961), rev'd on other grounds, 370 U.S. 421 (1962). 
broadly classify religious freedom as the most important constitutional right, ${ }^{155}$ the virtual absence of cases in which the free exercise of religion is directly opposed by a purely private party's constitutional rights makes it unclear whether the courts will allow a free exercise claim to impede governmental efforts to eliminate racial discrimination in the private sector of society. ${ }^{156}$ There is at least one case, however, involving the application of a civil rights statute to the practice of private racial discrimination free of any government support. In Newman v. Piggie Park Enterprises, Inc. ${ }^{157}$ black plaintiffs brought an action under the Civil Rights Act of 1964 against a restaurant owner for refusing them service on account of race. The defendant claimed that his religious beliefs compelled him to oppose any integration of the races whatever and that, consequently, application of the Act to his business would infringe his freedom of religion under the first amendment. The court, without even questioning whether the defendant's claimed belief was indeed religious, held that the government's interest in eliminating discrimination, as expressed by Congress in the Act, overrode any interest the defendant had in the free exercise of his religion:

Undoubtedly [the defendant] has a constitutional right to espouse the religious beliefs of his own choosing, however, he does not have the absolute right to exercise and practice such beliefs in utter disregard of the clear constitutional rights of other citizens. This court refuses to lend credence or support to his position that he has a constitutional right to refuse to serve members of the Negro race in his business establishments upon the ground that to do so would violate his sacred religious beliefs. ${ }^{158}$

The situation in Newman and the case of a commercially operated private sectarian school which denies admission to blacks have several facts in common: a business establishment evidently open to the public at large, refusal by the proprietor to admit blacks based upon purported religious beliefs against racial integration and a congressional statute prohibiting discrimination on racial grounds. The Newman court did not hesitate to hold that the claimant's rights under the free exercise clause were subordinate to

155. See, e.g., Unitarian Church West v. McConnell, 337 F. Supp. 1252, 1257 (E.D. Wis. 1972) (dictum), aff'd mem., 474 F.2d 1351 (7th Cir. 1973), vacated on other grounds, 416 U.S. 932 (1974) ("In the whole galaxy of constitutional rights, there is none that is more important than the "freedom of religion'").

156. Although there is a series of cases holding that the government's intercst in eliminating private racial discrimination, grounded in the Civil War amendments, outweighs free exercise claims, these cases all involve private institutions receiving direct or indirect financial assistance from the government. The state action factor inherent in these cases distinguishes them, to some extent, from cases involving parties completely independent of the government. See text accompanying notes $162-80$ infra.

157. 256 F. Supp. 941 (D.S.C. 1966), rev'd in part on other grounds, 377 F.2d 433 (4th Cir. 1967), aff'd per curiam, 390 U.S. 400 (1968).

158. 256 F. Supp. at 945 (emphasis added). 
the government's interest in guaranteeing blacks equal access to certain business establishments. ${ }^{159}$ Admittedly, the "religious" belief claimed by the proprietor in Newman, occurring in the context of operating a restaurant as compared with admissions to a sectarian school, is less likely to be considered sincerely held than the beliefs held by schools such as Dade Christian. ${ }^{160}$ But the Newman court's analysis of the balancing of the governmental and religious interests remains sound and should be fully applicable to cases such as Brown. ${ }^{161}$

159. Note that the constitutional authority for Congress' interest in eliminating racial discrimination in cases such as Newman and Bob Jones Univ. v. Johnson, 396 F. Supp. 597 (D.S.C. 1974), aff'd mem., 529 F.2d 514 (4th Cir. 1975), which were brought under the Civil Rights Act of 1964, was the commerce clause rather than the thirteenth amendment. See Katzenbach v. McClung, 379 U.S. 294 (1964); Heart of Atlanta Motel, Inc. v. United States, 379 U.S. 241 (1964). Since Congress' power to override free exercise objections to the prohibition of the practice of racial segregation was sustained by the courts in these cases on the basis of the commerce clause, the governmental interest in insuring racial equality should be even greater under the power granted Congress by the thirteenth amendment to eradicate the badges and incidents of slavery.

160. See note 71 supra and accompanying text.

161. An exception to the predominance of the government's interest over free exercise rights is a line of cases holding that, notwithstanding apparent violations of section 1981 and other civil rights legislation, the first amendment withdraws from civil courts subject matter jurisdiction to decide ecclesiastical issues which are "solely intertwined within private religious denominational practices." 40th St. and Fairmount Ave. Church of God v. Stover, 316 F. Supp. 375, 376 (E.D. Pa. 1970) (emphasis added). In Stover, black church members alleged that the defendant church denied the plaintiffs power of effective representation within the church by excluding blacks from the church's policy-making establishments. The court refused to decide whether the plaintiffs' free exercise of religion had been violated, stating that to decide the issues presented would violate the first amendment: "[W]hether the challenged policy is conservative or liberal, racially restrictive or interracial, the courts cannot adjudicate the orthodoxy of the religious policy and give relief to either group." Id.

In Simpson v. Wells Lamont Corp., 494 F.2d 490 (5th Cir. 1974), a pastor brought an action against a church alleging that he had been dismissed on racial grounds in violation of section 1981 and the first amendment; apparently, his wife was nonwhite and he had spoken out against the segregated nature of the church: Id. at 492-93. The court held that because the interaction between the church and its pastor is "an integral part of church government," the first amendment barred determination of the parties' rights and liabilities. Id. at 493. (In dicta, the court indicated that the church's free exercise right to control its operations as it saw fit outweighed any interest which the government or plaintiffs may have had in the elimination of racial segregation. Id. at 494.) See generally Kedroff v. St. Nicholas Cathedral, 344 U.S. 94 (1952) (state statute undertaking to transfer control of certain churches from foreign governing hierarchy to another governing authority held unconstitutional as prohibiting free exercise of religion); Catholic Bishop v. NLRB, 559 F.2d 1112 (7th Cir. 1977), cert. granted, 46 U.S.L.W. 3526 (U.S. Feb. 21, 1978) (NLRB does not have jurisdiction over secondary diocesan schools operated by Roman Catholic Church with respect to collective bargaining by lay teachers due to Church's first amendment rights of free exercise of religion); McClure v. Salvation Army, 460 F.2d 553 (5th Cir.), cert. denied, 409 U.S. 896 (1972) (application of Civil Rights Act provisions concerning equal employment opportunities to relationship between Salvation Army and one of its officers who was minister would result in encroachment by state into area of religious freedom in violation of first amendment).

Compare Stover and Simpson with Whitney v. Greater N.Y. Corp. of Seventh-Day Adventists, 401 F. Supp. 1363 (S.D.N.Y. 1975), in which the white plaintiff, employed as a 
(b) Government supported racial discrimination. A line of cases and administrative rulings involving state and federal government funding of racially discriminatory institutions, though clearly not controlling, is helpful in attempting to balance the interests in the Brown situation. The courts and the Internal Revenue Service (IRS) have uniformly concluded that the governmental interest in eliminating the practice of racial discrimination by private institutions receiving public support is sufficient to override a free exercise claim. Although these cases hold only that the first amendment provides no right to governmental support for racially discriminatory activities, ${ }^{162}$ they also stand for the broader proposition that a free exercise claim can be outweighed by the constitutional mandates of the fifth ${ }^{163}$ and fourteenth amendments ${ }^{164}$ prohibiting federal and state governments, respectively, from practicing, or assisting the private practice of, racial discrimination. Thus, these cases are an example of situations in which a constitutional interest in the prohibition of racial discrimination, though based upon a different constitutional provision than is section 1981, has been held to be more compelling than an opposing free exercise claim. They thereby bolster the argument that the governmental interest represented by section 1981 in outlawing racial discrimination-grounded in the thirteenth amendment—can also, at least in some cases, outweigh a free exercise claim.

The IRS in Revenue Ruling $75-231^{165}$ held that the federal public policy against racial discrimination in public and private education out-

typist-receptionist by a church, alleged that she had been discharged from her job and evicted from her church-owned apartment solely because she had been maintaining a casual social relationship with a black man. The court, distinguishing between the discharge of a typistreceptionist in Whitney and of a church official, as in Simpson and McClure, held that the plaintiff had stated a claim for relief under section 1981 and the unlawful employment practices provisions of the Civil Rights Act of 1964. According to the court, nothing in the record showed that the plaintiff's discharge was based upon the church's doctrinal policies or that the "relationship between the church and its clerical help touches so close to the heart of church administration as to be protected by the First Amendment from the commands of Title VII [of the Civil Rights Act of 1964]." Id. at 1368.

162. See, e.g., Bob Jones Univ. v. Johnson, 396 F. Supp. 597, 607 (D.S.C. 1974), aff'd mem., 529 F.2d 514 (5th Cir. 1975); Green v. Connally, 330 F. Supp. 1150, 1168 (D.D.C.), aff'd mem. sub nom. Coit v. Green, 404 U.S. 997 (1971).

163. See Bob Jones Univ. v. Johnson, 396 F. Supp. 597, 608 (D.S.C. 1974), aff'd mem., 529 F.2d 514 (5th Cir. 1975) ("the federal government cannot, consistent with the Due Process Clause of the Fifth Amendment, provide direct grants-in-aid to public or private entities which discriminate on the basis of race"), and authorities cited therein; $c f$. Bolling v. Sharpe, 347 U.S. 497 (1954) (racial segregation in public schools of District of Columbia is a denial of due process of law guaranteed by fifth amendment).

164. See Norwood v. Harrison, 413 U.S. 455, $463-65$ (1973), and authorities cited in id. at 463 n.6; Griffin v. County School Bd., 377 U.S. 218, 232 (1964); Brown v. Board of Educ., 347 U.S. 483 (1954).

165. $1975-1$ C.B. 158. 
weighed an institution's or individual's right to the free exercise of religion even where a tenet of the religion required that the school maintain a racially discriminatory policy as to the admission of students. ${ }^{166}$ Reaching a similar conclusion with respect to free association rights in upholding a prior IRS ruling ${ }^{167}$ that racially discriminatory private schools are not entitled to federal tax exemption as charitable institutions, the court in Green $v$. Connally ${ }^{168}$ stated:

There is a compelling as well as a reasonable government interest in the interdiction of racial discrimination which stands on highest constitutional ground, taking into account the provisions and penumbra of the Amendments passed in the wake of the Civil War. That government interest is dominant over other constitutional interests to the extent that there is complete and unavoidable conflict. ${ }^{169}$

There is clearly a "complete and unavoidable conflict" between the governmental interests in prohibiting racial discrimination and insuring equality of contractual opportunity, as reflected in section 1981, and a private sectarian school's interest in the free exercise of its religion insofar as it relates to denying admission to blacks. ${ }^{170}$ Thus, following the Green court's reasoning, the governmental interests are dominant over the school's free exercise interest.

A similar issue was raised in Bob Jones University v. Johnson, ${ }^{171}$ the primary differences being that the university asserted a free exercise claim and that the governmental assistance involved was in the form of direct

166. It is well-settled that a religious basis for an activity will not serve to preclude governmental interference with the activity if it is otherwise clearly contrary to Federal public policy. . . That those responsible for a given course of conduct may sincerely believe that they have a religious duty to act in a certain manner does not alter the situation.

Id. at 159. Rev. Rul. 75-231 withdrew tax exempt status as "charitable" organizations from institutions, including churches, that conduct private schools that practice racial discrimination. The ruling expressly applies to three similar types of church-school relationships, id. at 158 , the third of which accurately describes the New Testament Baptist Church and its subsidiary, Dade Christian. This was conceded by Dade Christian before the Supreme Court in Runyon. Brief of Dade Christian Schools, Inc., as Amicus Curiae, supra note 8, at 13. Virtually any private sectarian school denying admission to blacks on the basis of a claimed religious belief would fall within one of the three descriptions and would thus be subject to the IRS ruling.

167. Rev. Rul. 71-447, 1971-2 C.B. 230.

168. 330 F. Supp. 1150 (D.D.C.), aff'd mem. sub nom. Coit v. Green, 404 U.S. 997 (1971).

169. 330 F. Supp. at 1167 (emphasis added) (footnotes omitted), quoted in Bob Jones Univ. v. Johnson, 396 F. Supp. 597, 607-08 (D.S.C. 1974), aff'd mem., 529 F.2d 514 (4th Cir. 1975), Pitts v. Dep't of Revenue, 333 F. Supp. 662, 668 (E.D. Wis. 1971), and Cook v. Hudson, 511 F.2d 744, 751-52 (5th Cir. 1975) (Clark, J., dissenting), cert. dismissed, 429 U.S. 165 (1976). The basis of the holding in Green was that tax deductions and exemptions are not applicable to activities that are either illegal or contrary to public policy. $330 \mathrm{~F}$. Supp. at 1159-64.

170. See note 143 supra and text accompanying notes 142-43 supra.

171. 396 F. Supp. 597 (D.S.C. 1974), aff'd mem., 529 F.2d 514 (4th Cir. 1975). 
financial payments rather than federal tax exemptions. Bob Jones University held a deep religious conviction that the Bible forbids racial intermarriage, and it had exercised this religious belief for forty-five years since its founding by denying admission to unmarried nonwhites and by providing for the expulsion of students who dated members of any race other than their own. The policy was based upon the belief that segregation of the races is mandated by God and that the integration of the student body would lead to interracial marriage, thereby violating God's command. ${ }^{172}$ Notwithstanding that the university's policy was arguably not specifically directed against blacks, unlike Dade Christian's strictly segregationist position, the Bob Jones court held that the university's discriminatory policy necessitated the termination of federal assistance programs for veterans due to the application of the Civil Rights Act of 1964, which prohibits discrimination on grounds of race, color or national origin in programs receiving federal financial assistance. In rejecting the university's claim that the free exercise clause provided it with an absolute right to exclude black students from admission, the court stated:

The Constitution provides no absolute protection to invidious discrimination in the private sector. . . . There is no judicial support for the proposition that the First Amendment protection for the free exercise of religion is any more inviolable where it results in racial discrimination, than the First Amendment's secular protection of freedom of association which results in similar privately sponsored racial exclusion. The courts have not hesitated to reject the argument of freedom of association as a defense to an otherwise valid civil rights action. ${ }^{173}$

The court thus indicated that a genuine religious belief, protected by the first amendment and identical to that allegedly held by Dade Christian, ${ }^{174}$ was insufficient to prevail over the greater governmental interest in the elimination of private racial discrimination in the field of education.

The freedom of association defense alluded to in Bob Jones was

172. This belief is virtually identical to that allegedly held by Dade Christian. See text accompanying note 13 supra. The primary distinction between the exercise of this belief by the two schools is that Dade Christian refuses to admit any blacks while Bob Jones University excluded only unmarried blacks and those students who engaged in interracial dating. Although, being an elementary school, Dade Christian could not realistically be expected to modify its policy to reflect the more moderate position adopted by the university, the nature of the university's policy suggests that it is more likely to be based upon a sincerely held religious belief than is the absolute exclusion of blacks practiced by Dade Christian.

173. 396 F. Supp. at 607 (emphasis added). The court noted that this case did not present a direct challenge against continuation of the university's racist policy; rather, the federal government was seeking only to terminate its support of such discrimination pursuant to its congressional mandate. Id.

174. See note 172 supra. 
confronted by the Supreme Court in Norwood v. Harrison ${ }^{175}$ and in Runyon. In both cases the Court rejected the argument that the schools' practice of racial discriminaton could be protected by the first amendment guarantee of freedom of association:

[T]he Constitution . . . places no value on discrimination. . . . Invidious private discrimination may be characterized as a form of exercising freedom of association protected by the first amendment but it has never been accorded affirmative constitutional protections. And even some private discrimination is subject to special remedial legislation in certain circumstances under $\S 2$ of the Thirteenth Amendment; Congress has made such discrimination unlawful in other significant contexts. ${ }^{176}$

Although Norwood and Runyon make clear that freedom of association is not a sufficient defense to otherwise valid civil rights actions, neither case involved either sectarian schools or free exercise rights. The Runyon Court stated that while parents may have a first amendment right to send their children to schools that promote the belief that racial segregation is desirable, there is no constitutional right to practice the exclusion of blacks. ${ }^{177}$ It is questionable, however, whether it follows that, as indicated by the Bob Jones court, ${ }^{178}$ freedom of association may be freely analogized to freedom of religion. The result of the Bob Jones court's approach would be that the first amendment protects the teaching of a religious belief but not its practice. Yet the Supreme Court has left no doubt that the free exercise clause protects the practice of certain religious activities as well as the right to believe. ${ }^{179}$ Freedom of association, according to the Runyon analysis, is more akin to freedom of speech than to freedom of religion. Thus, in contrast to the conclusion of the Norwood Court, it appears that, in certain circumstances, not only may invidious private discrimination be characterized as a form of exercising the freedom of religion, but it may also be accorded affirmative constitutional protection. Nevertheless, section 1981 is one of the examples of "special remedial legislation" enacted under section two of the thirteenth amendment referred to by the Norwood Court and, in certain circumstances, may prohibit the practice of racial discrimination even when undertaken as the exercise of religion. ${ }^{180}$

175. 413 U.S. 455 (1973) (state program under which textbooks were purchased by state and were lent to students in both public and private schools without reference to whether any participating private school had racially discriminatory policies unconstitutional in that it significantly aided a system of potentially racially discriminatory private schools).

176. Id. at $469-70$ (footnote omitted), quoted in Runyon v. McCrary, 427 U.S. 160, 176 (1976).

177. 427 U.S. at 176.

178. See text accompanying note 173 supra.

179. See note 96 supra and accompanying text.

180. Cf. United States v. Hunter, 459 F.2d 205 (4th Cir.), cert. denied, 409 U.S. 934 (1972) (provision of Civil Rights Act of 1968 prohibiting publication of discriminatory notice relating to 


\section{CONClusion}

A lawsuit under section 1981 by a black family against a private sectarian school which denies admission to blacks on the basis of a claimed religious belief presents the courts with a test of their ability and willingness to decide a case on pure legal theory as applied to the facts of the case. Theoretically, the court should determine whether the claimed belief is a religious belief entitled to protection under the first amendment and, if so, should decide whether the school's free exercise interest is outweighed by the government's interest in eliminating the practice of racial discrimination. The alternative is for the courts to allow considerations of equity and internal prejudice to play a role in the decisionmaking process.

The plaintiffs in a section 1981 action have two inherent advantages at the outset: an intrinsic judicial disposition against the practice of racial discrimination and a deep-seated reluctance on the part of most persons to accept the school's argument that its policy of racial exclusion is truly religious in nature. Even if the court decides that the school's belief is

sale or rental of dwelling as applied to newspapers does not violate first amendment freedom of press); United States v. Mitchell, 327 F. Supp. 476 (N.D. Ga. 1971) (provision of Civil Rights Act of 1968 prohibiting inducing for profit any person to sell or rent any dwelling by representations regarding entry or prospective entry into neighborhood of person or persons of particular race or color, i.e. blockbusting, does not infringe first amendment freedom of speech); accord, United States v. Bob Lawrence Realty, Inc., 474 F.2d 115 (5th Cir.), cert. denied, 414 U.S. 826 (1973).

But cf. Joyner v. Whiting, 477 F.2d 456 (4th Cir. 1973), in which the president of a predominantly black state university withdrew financial support from the official student newspaper because of its segregationist editorial policy. The university claimed that the fourteenth amendment and the Civil Rights Act of 1964 barred state agencies from spending funds to discourage the racial integration of the university. The court held that the university's action abridged the newspaper's freedom of the press in violation of the first amendment in the absence of proof that the newspaper's editorial policy incited harassment, violence or interference with white students or faculty, or that the editor of the newspaper rejected any articles that were opposed to his editorial policy. Although the Joyner court's holding may appear contrary to other cases in which the state's interest in the elimination of racial segregation outweighed first amendment rights, Joyner may be distinguished in that no action was taken pursuant to any first amendment guarantees resulting in the infringement of the rights of others. The court's emphasis upon the necessity of the disputed action's having had some adverse effect upon the public was made evident by the court's noting the absence of proof relating to harm caused to whites. In Brown and nearly every other case where the governmental interest prevailed, on the other hand, it was clear that the rights of some members of the public had been infringed by the claimant's actions. See notes 144-45 supra and text accompanying notes $144-47$ supra.

See also Mitchell v. Pilgrim Holiness Church Corp., 210 F.2d 879 (7th Cir. 1954) (upholding the Fair Labor Standards Act as applied to employees of religious organization); see generally Justice Frankfurter's concurring opinion in Railway Mail Ass'n v. Corsi, 326 U.S. 88, 97-98 (1945):

Certainly the insistence by individuals on their private prejudices as to race, color or creed . . . ought not to have a higher constitutional sanction than the determination of a State to extend the area of non-discrimination beyond that which the Constitution itself exacts. 
religious and proceeds to balance the school's free exercise interest against the opposing governmental interest, the judge's possibly subconscious feeling that the belief is more philosophical than religious in nature is likely to cause him to weigh the school's interest less heavily than the law dictates. Of course, the establishment clause is supposed to prevent any such personal bias in favor of or against a particular religion from entering into judicial determinations, but it is understandably difficult for a judge's subconscious to pay heed to the dictates of the first amendment.

In most cases, the courts ought to treat the school's belief as religious in nature, if only because the preferred position of first amendment rights requires that the claimant receive the benefit of the doubt. Once that threshold determination has been made, the court must weigh the respective interests of the government and of the school, relying upon the facts in each case. Typically, as in Brown, the facts will indicate that the school's free exercise interest would not be so unduly infringed as to justify frustrating the governmental interest and harming the individual plaintiffs by allowing the school to continue its racially discriminatory admissions policy. In some cases, however, it is possible that the facts would demand that greater importance be accorded the religious interest, to the extent that the governmental interest is outweighed. Most commentators have stated that the religious interest will never, or only rarely, reach this high a level, ${ }^{181}$ but the final determination must be left to the courts on a case-by-case basis.

The commercial/noncommercial distinction noted by the Runyon Court with respect to the school's operation ${ }^{182}$ may serve a useful function in screening out cases involving noncommercially operated schools that are so private as to preclude the government from having any constitutional interest in their admission policies. Certainly this distinction would help solve the more sensitive cases involving what are essentially close personal relationships between teacher and pupil. Moreover, it would at least partially provide a response to the argument that section 1981 was intended to guarantee blacks the same access to necessary commercial trade and services as enjoyed by whites; the right to attend a racist private school preaching the virtue of racial segregation is hardly commensurate with the right to buy a train ticket or to get a job, which are the types of private contracts the drafters of section 1981 most likely had in mind when they

181. Commentators who argue that the governmental interest in the elimination of racial discrimination represented by section 1981 should prevail over a private sectarian school's religious belief requiring the exclusion of black students include Hilton, supra note 138, at 377; Note, supra note 27, at 257-58; Note, supra note 70, at 434-37; 91 HARV. L. REv., 879, 886 (1978). See generally Note, supra note 136, at 438 (Runyon indicates that scope of section 1981 will rarely, if ever, be cabined by countervailing constitutional rights).

182. See text accompanying notes 148-152 supra. 
guaranteed blacks the same contractual rights as are enjoyed by whites. ${ }^{183}$ Modern judicial and social attidues, however, demand that, except upon a showing of a countervailing constitutional interest of the greatest possible magnitude, all persons be allowed equal opportunity to enter into contracts for private schooling if such services are made available to the general public.

183. The object of the Civil Rights Act of 1866 , from which section 1981 is derived, "is to secure to a poor, weak class of laborers the right to make contracts for their labor, the power to enforce the payment of their wages, and the means of holding and enjoying the proceeds of their toil." CoNG. Globe, 39th Cong., 1st Sess. 1159 (1866) (remarks of Rep. Windom); accord, id. 1151 (remarks of Rep. Thayer); see id. 1833 (remarks of Rep. Lawrence) (section 1981 guarantees "the means by which citizens may exist"). Section 1981 was intended to preclude preferential treatment for whites in obtaining cabins on ships, buying train tickets, renting hotel rooms, receiving service in restaurants and obtaining church pews. Id. app., at 183 (remarks of Sen. Davis), cited in Jones v. Alfred H. Mayer Co., 392 U.S. 409, 435 (1968). 